\title{
Integration of Gasification and Solid Oxide Fuel Cells (SOFCs) for Combined Heat and Power (CHP)
}

\author{
Paula Costa *(D), Filomena Pinto (D), Rui Neto André and Paula Marques (D)
}

National Laboratory of Energy and Geology (LNEG), Estrada do Paço do Lumiar, 22, 1649-038 Lisboa, Portugal;
filomena.pinto@lneg.pt (F.P.); rui.andre@lneg.pt (R.N.A.); paula.marques@lneg.pt (P.M.)
* Correspondence: paula.costa@lneg.pt; Tel.: +351-21-092-4600 (ext. 4406)

check for

updates

Citation: Costa, P.; Pinto, F.; André, R.N.; Marques, P. Integration of Gasification and Solid Oxide Fuel Cells (SOFCs) for Combined Heat and Power (CHP). Processes 2021, 9, 254. https://doi.org/10.3390/pr9020254

Received: 31 December 2020

Accepted: 25 January 2021

Published: 29 January 2021

Publisher's Note: MDPI stays neutral with regard to jurisdictional claims in published maps and institutional affiliations.

Copyright: (c) 2021 by the authors. Licensee MDPI, Basel, Switzerland. This article is an open access article distributed under the terms and conditions of the Creative Commons Attribution (CC BY) license (https:// creativecommons.org/licenses/by/ $4.0 /)$.

\begin{abstract}
This paper reviews the most recent information about the main operations to produce energy from carbonaceous materials, namely biomass and wastes through the integration of gasification, syngas cleaning and solid oxide fuel cells (SOFCs), which have shown to be a good option for combined heat and power (CHP) production, due to high efficiency and low environmental impact. However, some challenges still need to be overcome, mainly when mixed feedstocks with high contents of hazardous contaminants are used, thus syngas cleaning and conditioning is of major importance. Another drawback is SOFC operation, hence new materials especially for the anode has been proposed and tested. An overall process to produce $\mathrm{CHP}$ by gasification integration with SOFC is proposed.
\end{abstract}

Keywords: gasification; syngas conditioning; solid oxide fuel cells (SOFC)

\section{Introduction}

The application of green technologies to produce energy creates possible ways for sustainable development. A solid oxide fuel cell (SOFC) is an attractive candidate for energy production from biomass generation that shows advantages in a variety of fuels, quiet operation, low or zero emission and high efficiency. The integration of the biomass gasification process (thermochemical system that converts carbonaceous materials into gaseous products in the presence of gasifying agents such as air, oxygen and steam either alone or in the mixture) with SOFCs shows that it is a positive route in using carbonaceous wastes and/or bioproducts as feedstock. The produced syngas (mainly composed by $\mathrm{H}_{2}$, $\mathrm{CH}_{4}, \mathrm{CO}$ and $\mathrm{CO}_{2}$ ) can be used as fuel for SOFCs to enrich the value of biomaterial as a energy resource from biomass. So, it can be considered that SOFCs are in focus to be integrated with biomass gasification technologies to have a single and highly efficient system; combining the benefits of renewable energy sources and hydrogen energy systems. However, an important aspect to take into account is that syngas needs to be cleaned to meet the requirement of SOFCs. Additionally, the development of new materials for SOFCs, more tolerant to contaminants, is a crucial point for the sustainability of the integrated systems, because it will contribute to increase the performance and the life time of the cell. This paper reviews the most promising gasification technologies for carbonaceous materials conversion into a gaseous mixture (syngas) to be used in SOFCs. Some focus will be given to novel and emerging gasification technologies. Syngas composition depends on the feedstock used, gasifier type and operating conditions. Usually syngas composition does not meet the requirements for SOFC use, thus downstream clean up and conditioning is needed. Hot syngas conditioning processes for different impurities are reviewed, as hot processes are the best option, because SOFCs operate at high-temperature. A suitable overall process to produce syngas to be used in SOFCs is proposed.

The main purpose of this review article is to present the fundamentals to implement biomass gasification integrated SOFC, for combined heat and power $(\mathrm{CHP})$ generation. 


\section{Biomass Gasification for Syngas Production}

Gasification converts carbonaceous materials into a gaseous mixture, generally named as syngas, which contains a mixture of $\mathrm{CO}, \mathrm{H}_{2}, \mathrm{CO}_{2}, \mathrm{CH}_{4}$ and other gaseous hydrocarbons, $\mathrm{H}_{2} \mathrm{O}$, tar, sulphur and nitrogen compounds (mainly $\mathrm{H}_{2} \mathrm{~S}$ and $\mathrm{NH}_{3}$ ) and other trace species. Syngas composition depends on the feedstock used, gasification technology, operational parameters, including gasification agent (steam, air, oxygen and $\mathrm{CO}_{2}$ ) and catalyst type. Some solids are also obtained, consisting mainly of char and ash. Table 1 summarizes the main reactions that occur during gasification.

Table 1. Main gasification reactions [1].

\begin{tabular}{|c|c|c|c|}
\hline & Reaction & $\Delta \mathrm{H}(\mathrm{kJ} / \mathrm{mol})$ & \\
\hline Oxidation & $\begin{array}{l}\mathrm{C}(\mathrm{s})+\mathrm{O}_{2} \leftrightarrows \mathrm{CO}_{2} \\
\mathrm{C}(\mathrm{s})+\frac{1}{2} \mathrm{O}_{2} \leftrightarrows \mathrm{CO} \\
\mathrm{H}+\mathrm{O}_{2} \leftrightarrows \mathrm{H}_{2} \mathrm{O} \\
\mathrm{CH} 4+\frac{1}{2} \mathrm{O}_{2} \leftrightarrows \mathrm{CO}+2 \mathrm{H}_{2} \\
\mathrm{CH} 4+2 \mathrm{O}_{2} \leftrightarrows \mathrm{CO}_{2}+2 \mathrm{H}_{2} \mathrm{O}\end{array}$ & $\begin{array}{l}-392.5 \\
-110.5 \\
-242.0 \\
-35.7 \\
-802.3\end{array}$ & $\begin{array}{l}(1) \\
(2) \\
(3) \\
(4) \\
(5)\end{array}$ \\
\hline Boudouard & $\mathrm{C}(\mathrm{s})+\mathrm{CO}_{2} \leftrightarrows 2 \mathrm{CO}$ & 172.0 & (6) \\
\hline \multirow{2}{*}{$\begin{array}{l}\text { Water Gas: primary } \\
\text { secondary }\end{array}$} & $\mathrm{C}(\mathrm{s})+\mathrm{H}_{2} \mathrm{O} \leftrightarrows \mathrm{CO}+\mathrm{H}_{2}$ & 131.4 & (7) \\
\hline & $\mathrm{C}(\mathrm{s})+2 \mathrm{H}_{2} \mathrm{O} \leftrightarrows \mathrm{CO}_{2}+2 \mathrm{H}_{2}$ & 90.4 & (8) \\
\hline Water-gas shift & $\mathrm{CO}+\mathrm{H}_{2} \mathrm{O} \leftrightarrows \mathrm{CO}_{2}+\mathrm{H}_{2}$ & -41.0 & (9) \\
\hline Steam Reforming & $\begin{array}{l}\mathrm{CH}_{4}+\mathrm{H}_{2} \mathrm{O} \leftrightarrows \mathrm{CO}+3 \mathrm{H}_{2} \\
\mathrm{CH}_{4}+2 \mathrm{H}_{2} \mathrm{O} \leftrightarrows \mathrm{CO}_{2}+4 \mathrm{H}_{2} \\
\mathrm{CnHm}+\mathrm{n} \mathrm{H}_{2} \mathrm{O} \leftrightarrows \mathrm{n} \mathrm{CO}+(\mathrm{n}+\mathrm{m} / 2) \mathrm{H}_{2} \\
\mathrm{CnHm}+\mathrm{n} / 2 \mathrm{H}_{2} \mathrm{O} \leftrightarrows \mathrm{n} / 2 \mathrm{CO}+(\mathrm{m}-\mathrm{n}) \mathrm{H}_{2}+\mathrm{n} / 2 \mathrm{CH}_{4}\end{array}$ & $\begin{array}{c}205.9 \\
164.7 \\
210.1 \\
4.2\end{array}$ & $\begin{array}{l}(10) \\
(11) \\
(12) \\
(13)\end{array}$ \\
\hline $\mathrm{CO}_{2}$ Reforming & $\begin{array}{l}\mathrm{CH}_{4}+\mathrm{CO}_{2} \leftrightarrows 2 \mathrm{CO}+2 \mathrm{H}_{2} \\
\mathrm{CnHm}+\mathrm{n} \mathrm{CO}_{2} \leftrightarrows 2 \mathrm{nCO}+\mathrm{m} / 2 \mathrm{H}_{2} \\
\mathrm{CnHm}+\mathrm{n} / 4 \mathrm{CO}_{2} \leftrightarrows \mathrm{n} / 2 \mathrm{CO}+(\mathrm{m}-3 \mathrm{n} / 2) \mathrm{H}_{2}+(3 \mathrm{n} / 4) \mathrm{CH}_{4}\end{array}$ & $\begin{array}{c}247.0 \\
292.4 \\
45.3\end{array}$ & $\begin{array}{l}(14) \\
(15) \\
(16)\end{array}$ \\
\hline Methanation & $\begin{array}{l}\mathrm{C}(\mathrm{s})+2 \mathrm{H}_{2} \leftrightarrows \mathrm{CH}_{4} \\
\mathrm{CO}+3 \mathrm{H}_{2} \leftrightarrows \mathrm{CH}_{4}+\mathrm{H}_{2} \mathrm{O} \\
2 \mathrm{CO}+2 \mathrm{H}_{2} \leftrightarrows \mathrm{CH}_{4}+\mathrm{CO}_{2} \\
\mathrm{CO}_{2}+4 \mathrm{H}_{2} \leftrightarrows \mathrm{CH}_{4}+2 \mathrm{H}_{2} \mathrm{O}\end{array}$ & $\begin{array}{l}-74.6 \\
-205.9 \\
-247.3 \\
-164.9 \\
\end{array}$ & $\begin{array}{l}(17) \\
(18) \\
(19) \\
(20)\end{array}$ \\
\hline \multirow{2}{*}{ Decompositions of tar/hydrocarbons } & $\mathrm{pCxHy} \leftrightarrows \mathrm{qCnHm}+\mathrm{rH}_{2}$ & & (21) \\
\hline & $\mathrm{CnHm} \leftrightarrows \mathrm{nC}+\mathrm{m} / 2 \mathrm{H}_{2}$ & & (22) \\
\hline
\end{tabular}

\subsection{Feedstock Composition and Gasification Operating Conditions}

Feedstock composition, gasifier type and operating conditions are the main issues that affect syngas yield and composition. Many researchers have studied gasification of many types of feedstocks, mainly coal, biomass and wastes, either used alone or in mixtures and a huge amount of publications may be found in the literature. Feedstock to be gasified needs to have the right physical and chemical properties, as they affect syngas composition, cleaning, upgrading and end-uses. Low moisture content is a key issue, as moisture reduces gasification thermal efficiency, because of the energy spent on biomass drying inside the gasifier and of gasifier temperature reduction, leading to the release of more tar. Feedstock density is also important, as it affects transportation, gasifier feeding and performance [2]. In relation to chemical composition, Ren et al. [3] stated that usually the higher the ratio (hemicellulose + cellulose)/lignin the higher syngas production, as wood, straw and plant biomass present higher content of cellulose, whilst shells contain more lignin, generally the latter produce less syngas. Feedstocks should also have high calorific value, low ash and low contents of undesirable elements like chlorine and sulphur. High ash content causes agglomeration, erosion and corrosion problems. High sulphur, nitrogen and chlorine contents promote the formation of high $\mathrm{H}_{2} \mathrm{~S}, \mathrm{NH}_{3}$ and $\mathrm{HCl}$ contents. The use of mixtures of different feedstocks in cogasification processes may be beneficial to decrease the contents 
of undesirable components, as stated by Pinto et al. [4] about cogasification of low grade coals (with high ash and sulphur contents) blended with different types of biomass and wastes. On the other hand, the use of polyethylene in the coal blends studied, favored the formation of tar and gaseous hydrocarbons, which also increased syngas calorific value.

Gasifier operating conditions are also a key issue in syngas yield and composition. The most important parameters are: temperature, gasification agent and residence time. Many researchers have investigated the effect of operating conditions, namely Watson et al. [5] that reviewed the effect of gasification parameters and gasifier types. High temperature favors gasification process and thus carbon conversion increases, while tar content in syngas decreases, enriching $\mathrm{H}_{2}$ and $\mathrm{CO}$ contents in syngas [6]. However, ash melting point limits gasification temperature. The increase of residence times has a similar effect as temperature. High residence times usually favors char reaction, and thus lower contents of char are obtained, the release of $\mathrm{S}, \mathrm{N}$ and $\mathrm{Cl}$ may be also favored, but the conversion of these elements compounds and of tar may be also favored. Hence residence time affects syngas composition, but its effect may act in opposite directions and thus it is not always easy to predict [7].

The use of steam as a gasification agent usually increases hydrogen content in syngas, while tar is reduced, as steam reforming reactions (12) and (13) are promoted. The rise of oxygen content (and of the ER-equivalent ratio) in the gasification medium promotes oxidation reactions (1) to (4) and thus the formation of $\mathrm{H}_{2} \mathrm{O}$ and $\mathrm{CO}_{2}$, while temperature increases. ER is defined as the ratio between the amount of oxygen used and the stoichiometric oxygen needed for complete combustion of the feedstock. The use of high ER values decreases syngas calorific value, hence ER in range of 0.2-0.4 are usually suitable to control tar release and syngas calorific value [7].

Another important issue is the low energy content of syngas when air is used as a gasification agent, due to the nitrogen diluting effect. To solve this problem pure oxygen could substitute air, as proposed in some concepts. However, the cost of oxygen production for the gasification installation would reduce its economic viability. Another option is the use of enriched air, with oxygen amounts higher than that found in air, like enriched air with $40 \%(v / v)$ of oxygen, as the production of this mixture by membrane technology presents a suitable price [8]. Nevertheless, the syngas obtained would contain some nitrogen and lower heating value than that obtained with pure oxygen. A new option could be the production of oxygen by water solar electrolysis and solid oxide electrolysis [9]. Oxygen will be used instead of air and the hydrogen produced could be mixed with syngas.

Feedstocks pretreatment is another key issue, the most common is drying to ensure moisture contents below $15 \%$ and may exclude gasification of some feedstocks, due to the price of drying operation. Milling to reduce particle size is another common pretreatment, but particle size depends on technology, fixed beds may process wastes up to $50 \mathrm{~mm}$, while entrained flows require much smaller particles usually below $500 \mu \mathrm{m}$ and fluidized beds in between $(0.5-5 \mathrm{~mm})$. On the contrary, some feedstocks require pelletization to increase density prior to gasification, decrease moisture and pathogen contents, facilitate inlet operation and improve uniformity and homogeneity inside the gasifier [10]. Torrefaction has also been considered as a pretreatment operation, as it increases energy density and feedstocks hydrophobic characteristics, thus allowing open air transportation and storage. Torrefaction treats feedstocks at $200-300{ }^{\circ} \mathrm{C}$ under minor air conditions for around $30 \mathrm{~min}[10]$.

Several authors have studied the presence of catalysts in gasification of different types of carbonaceous materials. The most tested catalysts were natural minerals, like: limestone, dolomite, olivine, limonite, activated carbon and different metal-based catalyst like iron, nickel, magnesium, etc. Ren et al. [3] compared the performance of different catalysts tested for gasification of several types of biomass and stated that Ni-based catalysts favor syngas production and promote tar cracking in presence of steam. Some additives (like $\mathrm{Ce}, \mathrm{La}, \mathrm{Mg}, \mathrm{K}, \mathrm{Mo}, \mathrm{Zr}$ and $\mathrm{Mn}$ ) could improve the performance and stability of Ni-based 
catalyst, particularly Mo, $\mathrm{Zr}$ and Mn led to the highest activity and stability during biomass gasification.

Due to the austere conditions inside the gasifier, low cost minerals are the best option. Though the best results have been obtained with some metal-based catalysts, like nickel for instance, the high cost and fast deactivation prohibits its use inside the gasifier and advises its utilization for syngas conditioning.

\subsection{Gasifier Type and Design}

Another important issue is the gasifier design. Gasifiers may operate in two distinct ways and syngas quality depends on the method used to provide the heat needed for primary endothermic reactions. In direct or autothermal gasification, air or oxygen is supplied to the gasifier to promote partial oxidation of the feedstock and supply the needed heat to the process. When air is used, the produced gas has low heating values (in the range of 4-7 $\mathrm{MJ} / \mathrm{Nm}^{3}$ ), due to a nitrogen diluting effect. On the other hand, in indirect or allothermal gasification, steam or $\mathrm{CO}_{2}$ or mixtures of both are used as gasifying agents, the product gas is free of nitrogen, but an external source of heat is needed.

There are mainly three types of gasifiers: fixed bed, fluidized bed and entrained flow. The first one is the original gasifier technology and the most used. Fixed beds are simple and reliable, with well-known technology. As they have low and non-uniform heat and mass transfer, high amounts of char, tar and particulates may be produced. There are three types of fixed bed gasifiers: updraft (or counter-flow gasifier), downdraft (or cocurrent) and crossdraft. These gasifiers are suitable for installation up to $10 \mathrm{MWe}$ and have proved perfect for power generation from biomass and in combination with internal combustion engines for decentralized installations [11]. Updraft gasifiers have the advantage of having high thermal efficiency and leading to lower char, but the disadvantage of slagging, especially for feedstocks with high ash content. In the downdraft gasifier, gas leaves at the bottom of the reactor at a higher temperature, thus with lower tar content. However, downdraft gasifiers are also unsuitable for feedstocks with high ash content and low ash fusion temperatures, as slagging and clinker formation may occur. In crossdraft gasifiers gasification medium is introduced in the side of the gasifier near the bottom, as in the down draft gasifiers, but gas leaves the reactor on the opposite side [1].

Fluidized bed gasifiers (bubbling and circulating) require biomass pretreatment to reduce the particle size, but they have the advantages of uniform heat and mass transfer, due to the use of hot inert bed materials, usually silica sand $[1,3,5,11]$. Thus, there are no distinct zones as in fixed beds and all the processes occur almost simultaneously. Bubbling fluidized beds are easy to design, to build, to operate and to control the temperature. However, due to the lower operating temperatures, around $800-900{ }^{\circ} \mathrm{C}$, the gasification gas contains tar $\left(10 \mathrm{~g} / \mathrm{Nm}^{3}\right)$, hydrocarbons and particulates and needs treating and upgrading. These problems may be reduced by using a circulating fluidized bed, as solids leaving the gasifier are collected in a cyclone and returned to the reactor, hence increasing carbon conversion. Slagging from ash may also be a problem. Despite the advantages of circulating fluidized beds, they are still less commonly used than bubbling fluidized bed, because they are more difficult to operate and control and have higher cost $[1,3,5,11]$.

Entrained flow gasification was developed for the coal industry. Feedstocks with very small particle sizes are required, thus this type of gasifier is not suitable for some feedstocks, due to the difficulty of grinding these materials. Feedstock and oxygen (generally used instead of air) usually flow in cocurrent operation and the gasification reactions occur without separate zones. Entrained flow gasifiers use high temperature up to $1300{ }^{\circ} \mathrm{C}$, thus, leaving syngas has low contents of tar and hydrocarbons $[1,3,5,11]$. Another benefit of entrained flows is the removing of ash as a slag at a temperature above the ash fusion one, which avoids bed agglomeration. Nevertheless, operation costs are higher than in the other described reactor types and capital costs are also higher, due to the need of expensive materials of construction and more complex fabrication. The need of using pulverized feedstocks is an important drawback, as a great deal of energy is required. 
However, this disadvantage may be overtaken by pretreating the carbonaceous materials prior to gasification, using torrefaction, slow pyrolysis, flash pyrolysis and prefluidized bed gasification $[1,3,5,11]$.

Plasma gasification is an emerging technology suitable for complex feedstocks like MSW, capable of producing a clean syngas with high-energy content $\left(12-15 \mathrm{MJ} / \mathrm{Nm}^{3}\right)$ and low amounts of solid are produced, converting ash into vitrified and inert slag. The main drawback is the use of very high temperatures (up to $5500{ }^{\circ} \mathrm{C}$ ), which require very high electricity consumption to run the plasma and the use of expensive advanced building material, thus this technology require high CAPEX and OPEX. New developments of plasma gasifiers have focused on decreasing energy consumption and capital cost and on increasing reliability and commercial availability [12].

Some developments of gasification technology include the two-stage gasifier of Technical University of Denmark (DTU) where oxidation and pyrolysis processes are separated. Heat for pyrolysis is also obtained by biomass partial oxidation and the radiant heat from the gasification region maintains the temperature in the pyrolysis region. Exhaust gases are used for biomass drying and indirectly heat the pyrolysis step [9]. The main challenges are ensuring low tar contents and increasing syngas heating value, cold gas efficiency and carbon conversion.

The DFBG (dual fluidized bed gasifier) also uses two separate chambers, fluidized bed acts as the gasification unit and the other as a combustion unit. The inert solids moving from one reactor to the other, transfer heat from the combustion unit to the gasification bed. Besides this, other advantages are the bed material can carry char from gasifier to combustor and the bed material can be a carrier of catalytic species. The adaptation of DFBG to the chemical looping system is expected to improve the performance, namely by decreasing tar release, and to increase economic viability [13]. Transport gasifier is a variation of fluidized bed gasifiers that integrates features of entrained-flow and fluidized bed gasifiers. So far the performance of the DFBG has not yet been completely shown [14].

The most recent progress in gasification technology has focused on producing syngas with minimum cleaning requirements. The main objective was to design single reactors with multistage gasifiers. It has been developed an option that includes post gasification tar reformers within the single reactor [11]. Investigation interest has also risen in plasma gasification for both small scale and larger-scale operations. The Woodroll process uses an entrained flow gasifier that operates at around $1100{ }^{\circ} \mathrm{C}$ and at atmospheric pressure. The previously pyrolyzed char is gasified with steam and the gas obtained in the initial pyrolysis process is used as a fuel for internal heating of the plant facilities [15].

There are several small-scale commercial gasifiers, Thomson et al. [11] presents a list of manufacturers and the key gasifier technology for the production of syngas and with output between $70 \mathrm{kWe}$ and 3 MWe. In Table 2 some examples of manufacturers for commercial available gasifiers technology are presented. Typical gasifier performance is also listed by Thomson et al. [11].

For small-scale operation, the most recent developments have added some modifications to the classic designs of fixed bed gasifiers, namely the design of the throat, the size of the hearth mantle and the location and shape of the air nozzles. One of the main innovations has been the separation of reaction zones for fixed-bed gasification with the aim of improving control and decreasing tar and particulates release [11]. However, this concept increases the scale and the overall cost. Additional investigations have focus on developing alternative concepts of segregated processing with more automation and control and on creating modular systems to offer scale and operational flexibility [11]. 
Table 2. Examples of manufacturers of key gasifier technology [11].

\begin{tabular}{|c|c|c|}
\hline Gasifier Technology & Manufacturers & Reference \\
\hline \multirow{12}{*}{ Downdraft gasifier } & Aries Clean Energy & [16] \\
\hline & Bioresidues Energy Technologies & [17] \\
\hline & Holzenergie wegscheid & [18] \\
\hline & Infinite Energy & [19] \\
\hline & LiPRO Energy GmbH \& Co. KG Germany & [20] \\
\hline & URBAS & [21] \\
\hline & Joos downdraft gasifier-Spanner Re2 & [22] \\
\hline & Ronda Engineering Srl & [23] \\
\hline & Xylowatt & {$[24]$} \\
\hline & TARPO & [25] \\
\hline & Community Power Corporation & [26] \\
\hline & BIO\&WATT Gasification s.r.l. & [27] \\
\hline \multirow{4}{*}{ Updraft gasifier } & ReGaWatt GmbH & [28] \\
\hline & Updraft co-current-Burkhardt Energie & [29] \\
\hline & PRM Energy Systems & [30] \\
\hline & Torbed & {$[31]$} \\
\hline \multirow{5}{*}{$\begin{array}{l}\text { Stratified combined } \\
\text { updraft/downdraft }\end{array}$} & A.H.T Pyrogas & [32] \\
\hline & BR Energy Group & [33] \\
\hline & Pyrox & [34] \\
\hline & Terruzzi Fercalx Energy Group & [35] \\
\hline & Chanderpur Works & [36] \\
\hline \multirow{2}{*}{ Fluidized bed gasifier } & Bubbling fluidised bed gasifier-EQTEC & [37] \\
\hline & Aries Clean Energy & [16] \\
\hline \multirow{2}{*}{ Entrained flow gasifier } & MEVA Energy & [38] \\
\hline & Woodroll ${ }^{\circledR}$ entrained flow gasifier-Cortus Energy & [39] \\
\hline
\end{tabular}

Besides the type of gasifier technology, a key issue is installation scale [11]. Largescale gasification installations focus on obtaining syngas to be used in chemical synthesis for fuels and chemicals production, to which gas cleaning and conditioning is of major importance. While small-scale decentralized installations focus on electricity generation and CHP systems, better overall system efficiency is usually achieved for smaller-scale systems that only need cheaper localized feedstock transportation [11].

Indrawan et al. [12] presents a list of the main characteristics of advanced commercial gasifiers with the design and the main features of each one. These authors also reviewed the features of advanced gasifiers suitable for biomass and solid waste applications. Some of these technologies are promising though they are still at the bench scale. Some designs combine bubbling, fluidized and fixed bed concepts, like: Milena, LT- low temperature circulating fluidized bed, two-stage fluidized catalytic and two-stage fluidized-entrained flow. Another design has emphasis on tar cracking like internal cyclonic downdraft and Viking gasifier. Supercritical water gasification is a new concept that has the advantage of dealing with feedstocks with high moisture contents and operates at conditions above those of water critical conditions. In Table 3 the main characteristics of some advanced commercial gasifiers are presented.

The key indicators for selecting gasification technology are strictly related with gasifier performance and the production of clean syngas with minor needs of upgrading. Several authors have selected different parameters, but according to Thomson et al. [11] those presented in Table 4 should be considered.

The challenges of biomass and wastes gasification include the development of technologies that allow the use of mixed feedstock with higher contents of moisture and hazardous contaminants, like RDF (residual derived fuel) for instance, with minimization of fouling and slagging. Another important issue is the operation at reduced temperatures, for capital and operating costs reduction, or increasing the durability of building materi- 
als and refractories, but ensuring the production of cleaned syngas with minor needs of conditioning and upgrading for application in solid oxide fuel cells.

Table 3. The main characteristics of some advanced commercial gasifiers [11,12].

\begin{tabular}{ccc}
\hline Technology & Main Characteristics & Reference \\
\hline UNIQUE & $\begin{array}{c}\text { Integrates gasification, gas cleaning (catalytic filter candle in the } \\
\text { freeboard) and conditioning in one single unit. Air or steam } / \mathrm{O}_{2} \text { are } \\
\text { used as gasification medium. Tar levels of } 1 \mathrm{~g} / \mathrm{Nm}^{3} \text { are reported. }\end{array}$ \\
\hline Milena & $\begin{array}{l}\text { Pyrolysis }(\mathrm{CFB}) \text { and combustion (i.e., BFB) are performed in two } \\
\text { separate, sequential reactors that are integrated in one refractory } \\
\text { lined container. Air is used as gasification medium. The dilution of } \\
\text { the syngas by } \mathrm{N}_{2} \text { (from the air stream) and } \mathrm{CO}_{2} \text { and } \mathrm{H}_{2} \mathrm{O} \text { (from the } \\
\text { combustion section) is minimized. }\end{array}$ \\
\hline
\end{tabular}

combustion to generate high-temperature combustion flows. Air is combustion to generate high-temperature combustion flows. Air is
used as gasification medium to produce syngas with tar content (300-400 mg/ $\left.\mathrm{Nm}^{3}\right)$.

Combine pyrolysis and gasification. Air is used to produce syngas

Two-Stage Fluidized Catalytic

Two-Stage Fluidized-Entrained Flow

Drop through plasma Heliostorm ${ }^{\mathrm{TM}}$ gasifier

Floating bed gasifier with low tar content $\left(<15 \mathrm{mg} / \mathrm{Nm}^{3}\right)$. Cold gas efficiency (CGE) of $93 \%$ and electrical efficiency of $25 \%$ are obtained.

Multi-stage (Viking gasifier)

Dual fluidized bed reactors and nickel-based catalytic filters are

Güssing fluidized bed inserted in the gasifier freeboard, using air/steam as gasifying agent, produces low $\operatorname{tar}\left(2-5 \mathrm{~g} / \mathrm{Nm}^{3}\right)$ and particulate matter.

Suitable to deal with difficult biomass (straw, manure fibers, sewage sludge). Consists of two gasification stages. In the first one is used $\mathrm{CFB}$ at $630{ }^{\circ} \mathrm{C}$ and the second one uses BFB at $730^{\circ} \mathrm{C}$. CGE from $87 \%$

LT-Circulating Fluidized Bed (CFB) to $93 \%$ is reported,
In the first stage a fluidized bed with silica sand is used and in the second stage a fix bed with catalyst for tar reforming is used. Tar content of $60 \mathrm{mg} / \mathrm{Nm}^{3}$ was reported.

In the first stage the fluidized bed operates at $650{ }^{\circ} \mathrm{C}$ and in the second stage the entrained reactor operates at $1300{ }^{\circ} \mathrm{C}$. Syngas is produced free of tar and a CGE up to $64 \%$ is obtained.

Ionic Gasification, very high temperature of $10,000{ }^{\circ} \mathrm{C}$ is obtained in

the core reaction zone. Carbon vaporizes at this temperature, breaking down into gaseous carbon atoms. Feedstock breaks down to individual atoms, leading to clean syngas without by-products, tar or harmful components.

In conventional fixed bed reactors the force of gravity and the gas flow act downwards and increases compression, while in the floating fixed bed reactor from SYNCRAFT these two forces act in opposition.

Thus, feedstock inside the gasifier remains loosened and well permeable. The innovative floating fixed bed technology, leads to the highest degree of efficiency and allows the maximum raw material flexibility with economic advantages.

Deals with wet and high moisture content feedstocks, without the need of pre-drying. Operates at conditions above those of supercritical water $\left(22 \mathrm{MPa}\right.$ and $\left.374^{\circ} \mathrm{C}\right)$.
Supercritical water

Up to now no commercial gasifiers can produce syngas that meets the requirements for use in fuel cells, namely SOFC, but generally downstream clean up and conditioning is required. 
Table 4. Key indicators for selecting gasification technology [11].

\begin{tabular}{|c|c|}
\hline Key Indicator & \\
\hline Tar before gas cleaning & $5-50 \mathrm{mg} / \mathrm{Nm}^{3}$ of tar in producer gas leaving \\
\hline Syngas heat content (LHV) & $\begin{array}{l}\text { Depends on gasification agent from } 4-7 \mathrm{MJ} / \mathrm{Nm}^{3} \text { (with air) to } \\
10-12 \mathrm{MJ} / \mathrm{Nm}^{3} \text { (with } \mathrm{O}_{2} \text {, steam, } \mathrm{CO}_{2} \text { ) }\end{array}$ \\
\hline Syngas quality & Depends much on feedstock, technology and gasification conditions \\
\hline Cold gas efficiency & Usually in the range 75 to $90 \%$. \\
\hline Carbon conversion efficiency & Usually $>90 \%$ \\
\hline Biomass requirements (size and moisture content) & $\begin{array}{c}\text { Usually moisture contents below } 10-15 \% \\
\text { Particle size depends on technology (much smaller for } \\
\text { entrained flows) } \\
\text { Other feedstocks pre-treatments: torrefaction and pelletization }\end{array}$ \\
\hline Gasification temperature & $\begin{array}{l}\text { For fluidized bed gasifiers: } 800-850{ }^{\circ} \mathrm{C} \\
\text { For entrained flow gasifiers: } 1100-1300{ }^{\circ} \mathrm{C}\end{array}$ \\
\hline Exit gas temperature & Depends on technology usually $>800^{\circ} \mathrm{C}$ \\
\hline Scalability and modularity & $\begin{array}{l}\text { For the minimum size units: } 100-500 \mathrm{kWe} \text { Some units are scalable to } \\
\qquad 2 \mathrm{MWe} \text { or more. }\end{array}$ \\
\hline Catalyst/bed systems & Usually low cost minerals like: dolomite or olivine \\
\hline Technical complexity & $\begin{array}{l}\text { Technical complexity depends on the technology and increase CAPEX } \\
\text { and OPEX. General units have medium complexity and are semi } \\
\text { autonomous, except plasma gasifiers that are highly complex. }\end{array}$ \\
\hline
\end{tabular}

\section{Syngas Cleaning and Conditioning}

\subsection{SOFC Requirements for Syngas Utilization}

As mentioned before, syngas characteristics and quality is much dependent on feedstock composition. Gasification of wastes with considerable amounts of $\mathrm{S}, \mathrm{Cl}$ and $\mathrm{N}$ is expected to produce syngas with several undesirable impurities including: tar, particulate matter, $\mathrm{S}, \mathrm{Cl}$ and $\mathrm{N}$ compounds (mainly $\mathrm{NH}_{3}, \mathrm{HCl}$ and $\mathrm{H}_{2} \mathrm{~S}$ ). The formation of such undesirable compounds needs to be controlled and reduced during gasification by adjusting gasification operation conditions, like temperature and air (or oxygen) flow rate. However, most of the time, it is not possible to produce syngas with the required characteristics for its end-use, namely SOFC, thus syngas needs to be cleaned and conditioned. SOFC is a good option to use syngas, as its requirements for syngas composition are less demanding than those of other fuel cells (Table 5). Depending on initial syngas composition, expensive cleaning and conditioning technologies may be needed. Thus, the optimization of wastes gasification is a main issue to achieve the production of syngas with the minor contents of undesirable contaminants to its utilization in SOFC.

After syngas production by gasification, it needs to be cleaned and conditioned. Syngas clean-up usually means to remove undesirable compounds or contaminants like $\mathrm{H}_{2} \mathrm{~S}$ or $\mathrm{NH}_{3}$, for instance. Syngas conditioning generally means to change syngas composition to achieve a suitable composition for a specific end-use, for instance by the promotion of some of the reactions presented in Table 1. Several syngas cleaning and conditioning processes will be analyzed with the aim of removing particulate dust, tar and $\mathrm{S}, \mathrm{Cl}$ and other undesirable compounds. Special attention will be given to hot syngas cleaning technologies, including thermal catalytic reforming of tar, hydrocarbons abatement and water gas shift reaction, due to their efficiency and novelty.

New syngas cleaning and conditioning processes are at different stages of deployment, but some of them need further research and development, especially concerning the development of new catalysts, supporting materials and sorbents to improve the efficiency and selectivity of these syngas conditioning technologies. 
Syngas cleaning and conditioning processes are highly dependent on syngas end-use. Fuel cells and chemical synthesis are more demanding towards syngas composition than other utilizations. In Table 5 the main syngas requirements to be used in fuel cells are shown. High temperature fuel cells, like SOFC and MCFC, are less sensitive than low temperature fuel cells and they are better suited to use syngas. Values presented in Table 5 are the average ones, as variations of specific fuel cells may present different requirements. SOFCs may operate with syngas containing $\mathrm{CH}_{4}$ and other light hydrocarbons, but impurities like sulphur, chlorine, siloxanes and tars are forbidden, because they will not only interact with the Ni-anode of the SOFC, but also the performance of other components will be affected by their presence, in particular the fuel reformer. Reformer is likely to act as a trap for contaminants upstream of the SOFC depending on the type of catalyst used (either Ni-based or with noble metal catalysts [54]). Thus, syngas conditioning is mandatory.

Table 5. Requirements for syngas utilizations in a solid oxide fuel cell (SOFC) and comparison with other fuel cells MCFC (molten carbonate fuel cell), AFC (alkaline fuel cell), PEFC (polymer electrolyte fuel cell) and PAFC (phosphoric acid fuel cell) [55].

\begin{tabular}{|c|c|c|c|c|c|c|c|}
\hline Impurity & Particulate & $\begin{array}{c}\text { Total } \\
\text { Sulphur }\end{array}$ & Total Chlorine & $\mathrm{NH}_{3}$ & Tar & Alkali Metals & Others \\
\hline SOFC & 10-100 ppm & $<1 \mathrm{ppm}$ & $<1 \mathrm{ppm}$ & - & $<2000 \mathrm{ppm}$ & $<1 \mathrm{ppm}$ & - \\
\hline MCFC & $10-100 \mathrm{ppm}$ & $<0.5-1 \mathrm{ppm}$ & $1 \mathrm{ppm}$ & $1-3 \%$ vol & $<2000 \mathrm{ppm}$ & $<1 \mathrm{ppm}$ & \\
\hline AFC & $<100$ ppm & Poison & Poison & $\begin{array}{c}- \\
-\end{array}$ & Poison & Poison & Poisons: $\mathrm{CH}_{4}, \mathrm{CO}, \mathrm{CO}_{2}$ \\
\hline PEFC & $<100 \mathrm{ppm}$ & Poison & $<1 \mathrm{ppm}$ & $<1 \mathrm{ppm}$ & Poison & Poison & $\mathrm{CO}<10$ ppm \\
\hline PAFC & $<100$ ppm & $<50$ ppm & Poison & Poison & Poison & Poison & $\mathrm{CO}<500 \mathrm{ppm}$ \\
\hline
\end{tabular}

Hofmann et al. [56] tested an SOFC with a nickel gadolinium-doped ceria anode (NiGDC) for several hours at stable continuous performance, using gas with reduced tar levels below $0.5 \mathrm{~g} / \mathrm{Nm}^{3}$. Gas without prereforming of tar was also tested for $7 \mathrm{~h}$ (tar levels higher than $10 \mathrm{~g} \mathrm{Nm}^{3}$ ). These authors stated that the SOFC anode was not affected by carbon deposition or other impurity accumulation even when syngas with the higher tar content was tested, however, cell voltage output was slightly smaller. Nevertheless, these authors advise further studies to clearly understand the effect of heavy tars on SOFC operation.

Din and Zainal [2] compared the requirements of SOFC anodes: Ni-YSZ (nickel yttria stabilized Zirconia) and Ni-GDC and found that Ni-YSZ anodes are less tolerant to syngas contaminants than Ni-GDC, especially for tar and $\mathrm{H}_{2} \mathrm{~S}$. Ni-YSZ requires $\mathrm{H}_{2} \mathrm{~S}$ contents below 1 ppmv, while 3 to few ppmv may be accepted by Ni-GDC. The latter tolerates few hundreds ppmv or larger of tar, whilst, Ni-YSZ requires a few to few tens of ppmv.

Different approaches may be used for syngas cleaning: hot gas conditioning, wet scrubbing or dry/wet-dry scrubbing. These processes were reviewed by Milne et al. [57], some of them were used in demonstration plants, but some of them are not commonly accepted due to technoeconomic evaluation.

Mondal et al. [58] stated that syngas cleaning has to include the separation of char/soot particles (particulates) together with acid gasses. Char materials and ash could be removed from syngas in a two-stage water wash, containing a quench pipe (carbon separator) and a packed tower. For acid gas removal (including $\mathrm{H}_{2} \mathrm{~S}, \mathrm{COS}$ and $\mathrm{CO}_{2}$ ) several methods may be used: solvent absorption (wet process), using different chemicals: (i) monoethanol amine (MEA), (ii) di-ethanol amine (DEA), (iii) methyl-diethanol amine (MDEA) and (iv) FLEXSORB (hindered amines). MDEA, Rectisol and Selexol processes are largely used. Rectisol has high selectivity for $\mathrm{H}_{2} \mathrm{~S}$ over $\mathrm{CO}_{2}$ and also has more capacity to remove COS. These syngas acid components may also be removed by adsorption (warm process), using adsorbents like $\mathrm{ZnO} / \mathrm{CuO}, \mathrm{Cr}_{2} \mathrm{O}_{3}, \mathrm{Al}_{2} \mathrm{O}_{3}$, etc. As stated by these authors the amount of impurities to be removed from syngas depends on syngas application, its use in chemical synthesis requires a higher degree of cleaning in relation to its application in power generation.

Asadullah [59] reviewed cold syngas cleaning and hot syngas cleaning processes for different applications. Cold gas cleaning methods can be divided into dry syngas cleaning and wet syngas cleaning. In dry syngas cleaning are included: cyclone, rotating particle 
separators, electrostatic precipitators, bag filters, baffle filters, ceramic filters, fabric/tube filters, sand bed filters, adsorbers, etc. In wet syngas cleaning may be included: spray towers, packed column, scrubber (wash tower), impingement scrubbers, venture scrubbers, wet electrostatic precipitators, wet cyclone sand, etc. Hot gas cleaning can be attained by removing the impurities by physical filtration at hot conditions or by converting impurities, namely tar to gas by thermal cracking or by thermal catalytic cracking processes. The steps of the gas cleaning systems should be the minimum possible and depends much on initial syngas composition and on syngas application.

Wet scrubbing is an option when syngas utilization is at atmospheric pressure and at low temperature. Usually after the cyclone, syngas goes into cooling or scrubbing towers for heavy tars condensation. Venturi scrubbers are usually used for second wet scrubbing. Tar separation may also be achieved by using demisters, granular fillers and wet electrostatic precipitators (ESPs). The latter are more expensive than other tar removal systems. The main wet scrubbing drawbacks are tar disposal and the formation and accumulation of wastewater with organics, inorganic acids, $\mathrm{NH}_{3}$ and metals [58,59].

Some factors should be taken into account before the selection of the most suitable process, namely: required syngas purity for downstream application, syngas composition, temperature and pressure, process complexity, utility requirements, solvent degradation and loss and cost. A very important issue in the selection of the conditioning process is the temperature at which syngas is used.

\subsection{Hot Gas Cleaning and Conditioning Processes}

If syngas utilization requires high temperature, hot gas cleaning processes are the best option to achieve a good heat management, as cooling the gas in wet scrubbing units and reheating it afterwards would result in lower energy efficiency and higher operational costs. According to Asadullah [59] hot gas cleaning is more advantageous in terms of thermal efficiency than cold gas cleaning processes.

SOFC operates at high-temperature, being a good option when energy systems are designed via biomass gasification, due to similar high operational temperature of SOFC and biomass gasification process. SOFC also produces byproducts like heat, which is proper for cogeneration facilities [60].

Toonssen et al. [61] compared low temperature gas cleaning with high temperature gas cleaning process and found that the latter has the highest electrical exergy efficiency $(49.9 \%)$ and led to a slightly higher performance. As hot syngas conditioning processes is the most suitable option for syngas use in SOFCs it will be next analyzed with more detail.

The first steps of hot gas cleaning processes are separation devices (cyclones and filters) for particulates removal in which the high temperature of the syngas can be partly maintained. Particulate may contain unconverted residual carbon and inorganic compounds, in which are included alkali metals $(\mathrm{Na}$ and $\mathrm{K})$, alkaline earth metals $(\mathrm{Ca})$, silica $\left(\mathrm{SiO}_{2}\right)$, other metals such as Fe and $\mathrm{Mg}$ and also minor amounts of arsenic, selenium, antimony, zinc and lead [62]. Moreover, bed materials and/or catalysts used in fluidized bed gasifiers may also contribute to the particulate load [2]. Particulates size may vary from less than 1-100 $\mu \mathrm{m}$.

Particulate conditioning processes needs to remove particles up to below specific limits by keeping pressure drop within acceptable limits and should also attain reliable operation (tensile strength, sealing system, thermal transient, corrosion and ash accumulation).

Cyclones are a good option, as they are easy to operate, commercially available at relatively low prices and work at high temperatures, retaining the sensible heat in the syngas. Cyclones are efficient for removing particulates above about $5 \mu \mathrm{m}$. They can also remove some particulates in the range of $1-5 \mu \mathrm{m}$, but they are inadequate for submicron particulates removal, thus other devices are needed after cyclones [2]. Some tars and alkali material are also removed in cyclones by condensation, however, the vaporized forms of those constituents remain in the outlet gas. Electrostatic precipitators (ESPs) could be a good option for the removal of submicron particulates, as they operate at high 
temperature, but theirs high investment and operational costs are the main drawbacks. Thus, the combination of different particulate removal devices is usually needed. Another option is rigid filters (fabric, ceramic or metallic filters) as they operated up to $800{ }^{\circ} \mathrm{C}$ and removes submicron particle sizes. Din and Zainal [2] stated that the combination of cyclones with metallic or ceramic filters is a good choice for particulate removal when syngas is used in SOFCs. However, when this combination is used, near-dry condensing tar particles may cause filter plugging. Hence, these devices are usually combined with catalytic reforming.

Alkali metals (mainly $\mathrm{K}$ and $\mathrm{Na}$ ) may react with chlorine in feedstock to form $\mathrm{KCl}$, $\mathrm{NaCl}, \mathrm{ZnCl}$, etc. $\mathrm{NaCO}_{3}$ and $\mathrm{KCO}_{3}$ may also be formed. These compounds condense at temperatures less than $600{ }^{\circ} \mathrm{C}$ and originate particles of sizes below $5 \mu \mathrm{m}$, which can be removed by filtration. According to Din and Zainal [2], a possible option is to cool down syngas until $400-350{ }^{\circ} \mathrm{C}$ to remove alkali compounds, as tar would be in the vapor phase, it will not block the filters. However, this option would be at the expense of some heat loss. Alternatively, for temperatures higher than $600{ }^{\circ} \mathrm{C}$, sorbents like bauxite, kaolinite and activated alumina have proven to be suitable for the removal of alkali compounds below 1 ppm [2].

Tar is a complex mixture of condensable hydrocarbons, containing single and multiple ring aromatic compounds, being some of them complex polycyclic aromatics. As mentioned before tar removal is crucial, as tar condenses in pipes and form sticky deposits that may block syngas gas flow and they may cause filter plugging. As scrubbing treatments are economically unattractive and environmentally problematic, a good option is tar conversion into gases, by catalytic cracking reactions (21) and (22), steam reforming reactions (12) and (13) and $\mathrm{CO}_{2}$ reforming reactions (15) and (16), Table 1. Catalytic tar abatement is more beneficial than thermal processes, because of the lower temperature range $\left(500-900{ }^{\circ} \mathrm{C}\right)$ [2].

Different types of catalysts have been tested in these processes and they may be grouped as: natural minerals, like limestone, dolomite or olivine, metal alkalis such as: $\mathrm{KOH}, \mathrm{KHCO}_{3}$ and $\mathrm{K}_{2} \mathrm{CO}_{3}$; stable metals such as: nickel oxide and noble metals based compounds, which even if they have a higher efficiency, they have high costs. Din and Zainal [2] reviewed catalysts for tar cracking. Natural minerals may be used for primary tar reduction, but more effective catalysts, like metal based ones are needed afterwards. Metallic catalysts include $\mathrm{Ni}, \mathrm{Pt}, \mathrm{Co}, \mathrm{Mo}$ and $\mathrm{Ru}$, most of them supported in silica, alumina and zeolites. Ni based catalysts have shown good performance for tar abatement [4]. Most of catalysts are likely to deactivate because of poisoning, erosion, attrition (dolomite), fouling, thermal degradation and phase transformation.

Asadullah [59] stated that catalytic hot gas cleaning is a good option, as it can provide syngas with a high amount of combustible components with minimum tar and other poisonous components. The use of a catalytic guard bed before a secondary tar reforming catalyst reactor is advisable, as it improves the durability of the catalyst.

Dayton [63] studied tar destruction catalysts and also stated that the use of a guard bed with calcined dolomite followed by a fixed bed $\mathrm{Ni}$ catalyst reforming reactor at $800{ }^{\circ} \mathrm{C}$ was a good option for effective tar removal. Ni based catalytic should be used after $\mathrm{HCl}$ and $\mathrm{H}_{2} \mathrm{~S}$ removal to avoid poisoning. Some authors, like Wang L. et al. [64] studied catalysts prepared by the combination of stable metals such as: ruthenium or nickel bimetallics and Rapagnà et al. [65] tested trimetallic and ternary oxide structures catalysts for syngas methane reforming with steam and $\mathrm{CO}_{2}$. The best activity at $800{ }^{\circ} \mathrm{C}$ was obtained with $\mathrm{LaNi}_{0}{ }_{3} \mathrm{Fe}_{0} \cdot \mathrm{O}_{3}$, in the presence of hydrogen and with a large excess of steam. $\mathrm{CH}_{4}$ conversion reached $90 \%$ and around $90 \%$ (by weight) of tar was also converted. Research and development is still needed to find a new catalyst for tar abatement with good effectiveness, longer lifetimes, better mechanical strength and low cost.

The main sulphur contaminant in gasification gas is hydrogen sulphide $\left(\mathrm{H}_{2} \mathrm{~S}\right)$, carbonyl sulphide (COS) and sulphur dioxide $\left(\mathrm{SO}_{2}\right)$ may also be formed, but only in very small contents [7]. Chlorine is usually present in the form of alkali metal salts that vaporize at high temperatures and combine with water vapor to form $\mathrm{HCl}$. Sulphur and halogens 
based compounds in syngas are disadvantageous, because they lead to the formation of pollutants like $\mathrm{SO}_{\mathrm{x}}$ and $\mathrm{HCl}$ in the exhaust gas, they originate corrosion in pipes and equipment and they may also deactivate or poison catalysts used in thermal catalytic processes for tar hydrocarbons and $\mathrm{NH}_{3}$ abatement [7]. Besides, some syngas end-uses require very low sulphur and chlorine contents, chemical synthesis like Fischer-Tropsch and methanol synthesis require sulphur and chlorine contents below $1 \mathrm{ppm}$. Most fuel cells oblige sulphur and chlorine contents below $1 \mathrm{ppmv}$, because they cause electrode degradation [51]. Some $\mathrm{H}_{2} \mathrm{~S}$ may be removed inside the gasifier by using limestone or dolomite, but as the low $\mathrm{H}_{2} \mathrm{~S}$ contents required by SOFC cannot usually be achieved, an external unit for further $\mathrm{H}_{2} \mathrm{~S}$ reduction is required.

In hot gas cleaning processes syngas may go into a fixed bed reactor or guard bed with natural minerals, like: limestone $(\mathrm{CaO})$, dolomite $(\mathrm{CaO} \bullet \mathrm{MgO})$ or olivine $\left((\mathrm{Mg}, \mathrm{Fe}) \bullet 2 \mathrm{SiO}_{4}\right)$ that are cheap and easy to find and that have shown to be appropriate to retain sulphur, chlorine and other halogenides. The main problem of dolomite is its softness, which makes it easy to break and erode. Prabhansu et al. [62] reported that chlorine compounds in syngas may be removed by using solid slaked lime and limestone at temperatures in the range of $500-600{ }^{\circ} \mathrm{C}$, and that better materials used as sorbents at $600{ }^{\circ} \mathrm{C}$ could lead to the removal of alkali metals. Zinc, copper and caesium oxides have shown to be suitable to attain $\mathrm{H}_{2} \mathrm{~S}$ contents below $1 \mathrm{ppm}$. Zinc and copper oxides that exist in nature in abundance have the potential for $99 \%$ removal of sulphur compounds at above $300{ }^{\circ} \mathrm{C}$, but volatilize at temperatures in the range of $600-650^{\circ} \mathrm{C}$ [62]. Din and Zainal [2] states that to prevent $\mathrm{ZnO}$ reduction, the maximum operating temperature of $\mathrm{ZnO}$ sorbents is around $350-400{ }^{\circ} \mathrm{C}$. Alternatively, the combination with other metal oxides allows the increase of the operating temperature. Zinc ferrites $\left(\mathrm{ZnO} . \mathrm{xFe}_{2} \mathrm{O}_{3}\right)$ and zinc titanates $(\mathrm{ZnO} . x \mathrm{TiO} 2)$ have shown to be more strong sorbents for desulfurization. Some metal-based sorbents, such as zinc titanate and copper and manganese oxides, have also been tested for $\mathrm{H}_{2} \mathrm{~S}$ reduction, but besides being expensive they lose much activity at a temperature below $550{ }^{\circ} \mathrm{C}$ [66-68]. When $\mathrm{ZnO}$ sorbents are used, $\mathrm{HCl}$ removal needs to be done before $\mathrm{H}_{2} \mathrm{~S}$ because $\mathrm{Cl}$ reacts with $\mathrm{Zn}$ [2]. $\mathrm{HCl}$ may be removed at high temperature by adsorption. Na and $\mathrm{K}$ sorbents are capable of reducing $\mathrm{HCl}$ content until $1 \mathrm{ppm}$ at around $500-600^{\circ} \mathrm{C}$, which allows syngas SOFC utilization. According to Din and Zainal [2], $\mathrm{NaHCO}_{3}$ is a good option, as it reacts with $\mathrm{HCl}$ and form $\mathrm{NaCl}$, which has to be removed, because SOFCs require alkali metals content below 1 ppm (Table 5).

Biomass wastes gasification may produce syngas with relatively high $\mathrm{NH}_{3}$ contents, up to 6000 ppmv, and minor amounts of hydrogen cyanide (HCN) may also be found. Most syngas utilizations require low $\mathrm{NH}_{3}$ contents, $\mathrm{NH}_{3}$ is converted into $\mathrm{NO}_{\mathrm{x}}$, during oxidation reactions, whose contents may reach values above the legally accepted limits. Fuel cells usually imposed contents lower than $5000 \mathrm{ppm}$, while chemical synthesis only accepted values around $1 \mathrm{ppmv}$, but SOFC did not limit $\mathrm{NH}_{3}$ content (Table 5). However, $\mathrm{NH}_{3}$ may be removed from syngas by adsorption/desorption cycles using molecular sieves made of highly porous aluminum silicates (zeolites). Another possibility is the catalytic decomposition of $\mathrm{NH}_{3}$ into $\mathrm{N}_{2}$. Some authors have reported that metal based catalysts, like nickel-based ones at temperature in the range of $700-800^{\circ} \mathrm{C}$ that are efficient in tar reduction are also suitable for $\mathrm{NH}_{3}$ abatement $[69,70]$. Wang $W$. et al. [71] found that $\mathrm{NH}_{3}$ removal efficiency went down considerably in the presence of high contents of hydrocarbons when $\mathrm{Ni}$ based catalysts were used, probably because $\mathrm{NH}_{3}$ was less competitive for catalyst active sites than hydrocarbons. However, Pfeifer et al. [72] reported tar reduction around $98 \%$ and $\mathrm{NH}_{3}$ destruction of about $40 \%$ in the presence of the monolith type catalyst made from nickel-based catalysts at temperatures around $850{ }^{\circ} \mathrm{C}$. Some researchers have studied the possibility of reducing nitrogen compounds together with tar or $\mathrm{H}_{2} \mathrm{~S}$, using multifunctional catalysts. Gangwal et al. [73] studied several catalysts containing $\mathrm{Ni}, \mathrm{Co}$, Mo and $\mathrm{W}$ with $\mathrm{Al}_{2} \mathrm{O}_{3}, \mathrm{TiO}_{2}$ and other oxides as supports, combined with a zinc titanate sorbent at $725{ }^{\circ} \mathrm{C}$ and achieved $\mathrm{H}_{2} \mathrm{~S}$ and $\mathrm{NH}_{3}$ reductions. Pinto et al. [6,7] also found that 
the G-90 B 5 catalyst (supplied by C \& CS and containing $11 \%$ of $\mathrm{Ni}, 6-9 \%$ of $\mathrm{CaO}$ and $76-82 \%$ of $\mathrm{Al}_{2} \mathrm{O}_{3}$ ) was effective for tar, $\mathrm{NH}_{3}$ and $\mathrm{H}_{2} \mathrm{~S}$ reductions.

During tar abatement processes gaseous hydrocarbons are converted into $\mathrm{CO}, \mathrm{CO}_{2}$ and $\mathrm{H}_{2}$. However, after tar abatement, syngas may still contain significant amounts of $\mathrm{CH}_{4}$, because $\mathrm{CH}_{4}$ conversion is usually more difficult to achieve. SOFCs operate at high temperatures and are capable of internally reforming fuel gases (i.e., $\mathrm{CH}_{4}$ and other light hydrocarbons) without the use of a reforming catalyst. Thus, the presence of $\mathrm{CH}_{4}$, and other gaseous hydrocarbons is not a penalty for syngas use in SOFC, thus syngas may contain $\mathrm{H}_{2}, \mathrm{CO}_{2}, \mathrm{CH}_{4}$ and other hydrocarbons (low sensitivity to $\mathrm{CO}$ ) [74]. This SOFC feature offers a significant cost reduction, high efficiencies and fast load response. Steam reforming does not decrease the electric efficiency, as the hydrocarbon fuel is reformed to carbon monoxide and hydrogen. However, using only internal reforming may lead to several problems, due to the high content of carbon compounds able to promote the carbon deposition phenomena. This problem can be avoided with partial prereforming of syngas. During syngas hot treatment and conditioning, the conversion of $\mathrm{CH}_{4}$ and other gaseous occurs, being favored by the use of suitable catalysts, through catalytic steam reforming, according to reactions (10) and (11) and through $\mathrm{CO}_{2}$ dry reforming by reaction (14). During syngas hot treatment and conditioning, water gas shift reaction (9) occurs, which converts $\mathrm{CO}$ in presence of steam, producing additional hydrogen and $\mathrm{CO}_{2}$. This reaction is promoted by several catalysts used in syngas hot treatment, namely Ni-based catalysts (G-90 B 5) as reported by Pinto et al. [4].

Marcantonio et al. [75] developed a simulation model for a gasifier including gas clean-up, using Aspen Plus, based on a quasi equilibrium approach through Gibbs free energy minimization. A new hot gas cleaning process was tested, including a combination of catalyst inside the gasification reactor (calcined dolomite), catalysts in the freeboard and following sorbent reactors. The contaminants modeled were toluene, benzene, naphthalene, $\mathrm{H}_{2} \mathrm{~S}, \mathrm{HCl}$ and $\mathrm{NH}_{3}$. As some contaminants may interfere in the adsorption of others, different steps were considered. Syngas was proposed to go through catalytic filter candles and next into a high temperature unit with metal oxide sorbent for $\mathrm{H}_{2} \mathrm{~S}$ cleaning. In the next step alkali-based sorbents (sodium and potassium compound) were studied for $\mathrm{HCl}$ cleaning. The results obtained led to tar contents below $1 \mathrm{~g} / \mathrm{Nm}^{3}$ and inorganic contaminants under $1 \mathrm{ppm}$.

In Table 6 is summarized the main features of hot syngas cleaning and conditioning processes.

Although hot gas conditioning processes are more advantageous than cold gas cleaning in terms of thermal efficiency, gas conditioning steps needs to be reduced to a minimum to diminish syngas thermal loss.

Figure 1 presents a suggestion for syngas cleaning process, which may be simplified or complicated according to syngas initial composition, catalysts used in each process and SOFC specific requirements for syngas. For common syngas compositions low cost minerals may be selected for sulphur and halogens compounds abatement, but this unit may need to be divided into two, depending on initial syngas overall composition and the contents of these compounds. On the other hand, when syngas presents very low contents of undesirable contaminants including tar, operations (3) and (4) (in Figure 1) may be reduced to only one unit, using minerals, for instance dolomite or olivine as a catalyst. When syngas presents higher contents of these adverse compounds, instead of dolomite a more effective catalyst for tar reduction, like a nickel-based one, should be used. If this catalyst is a multifunction one, for instance a nickel based catalysts with also $\mathrm{CaO}$, sulphur retention also occurs [4]. However, for high contents of sulphur and halogens, syngas treatment with dolomite or other similar mineral, prior to the use of a more specific catalyst, would be advisable, to ensure a longer life for the more specific catalyst. Thus, a common process for syngas conditioning is proposed in Figure 1. 
Table 6. Hot syngas cleaning and conditioning processes $[2,55,62]$.

\begin{tabular}{|c|c|}
\hline Impurity & Syngas Conditioning Processes \\
\hline Particulate & $\begin{array}{c}\text { Hot cyclone Up to } 1000{ }^{\circ} \mathrm{C}-90-95 \% \\
\text { Hot membrane-99\% } \\
\text { Cyclones + sintered metal filter (up to } 400{ }^{\circ} \mathrm{C} \text { ) } \\
\text { Cyclones + ceramic filter (up to } 800{ }^{\circ} \mathrm{C} \text { ) }\end{array}$ \\
\hline \multirow[t]{2}{*}{ Alkali metals } & $\begin{array}{l}\text { Adsorption on solid sorbent, getter material. Above } 500^{\circ} \mathrm{C} \text {, the calcium-based sorbents } \\
\text { starts decomposing }\end{array}$ \\
\hline & Alkali getters at $\geq 600^{\circ} \mathrm{C}\left(\right.$ activated alumina at $\left.800^{\circ} \mathrm{C}\right)$ \\
\hline \multirow{2}{*}{ Tar } & $\begin{array}{l}\text { Hot catalytic/reforming (with Fe or Ni-based catalyst more effective then olivine or dolomite). Up to } \\
\qquad 1000^{\circ} \mathrm{C}-80-95 \%\end{array}$ \\
\hline & $\begin{array}{l}\text { 1st Step: catalytic cracking using dolomite at } 900{ }^{\circ} \mathrm{C} \text { in secondary bed or thermal cracking at } 1200{ }^{\circ} \mathrm{C} \text {. } \\
\text { 2nd step: cracking using Ni based catalyst at } 800{ }^{\circ} \mathrm{C} \text { (after } \mathrm{HCl} \text { and } \mathrm{H}_{2} \mathrm{~S} \text { removal) }\end{array}$ \\
\hline \multirow{3}{*}{ Total sulphur } & $\mathrm{ZnO}$ sorbent at $350-400{ }^{\circ} \mathrm{C} /$ Activated Carbon \\
\hline & Zn Titanate sorbent at $\sim 600^{\circ} \mathrm{C}$ \\
\hline & $\begin{array}{l}\text { Physical and chemical adsorption, } \mathrm{ZnO} / \mathrm{FeO} \text { sorbents. Catalysts like CoMo for COS conversion, } \\
\text { Ni- and Fe-based catalysts. At } 600-650{ }^{\circ} \mathrm{C}\end{array}$ \\
\hline \multirow[t]{2}{*}{ Total chlorine } & $\begin{array}{l}\text { Sorbents at high temperature } \\
\text { Activated carbon, alumina and common alkali oxides }\end{array}$ \\
\hline & $\mathrm{NaHCO}_{3} / \mathrm{Na}_{2} \mathrm{CO}_{3}$ up to $550-600^{\circ} \mathrm{C}$ \\
\hline $\mathrm{NH}_{3}$ & Thermal catalytic decomposition of $\mathrm{NH}_{3}$ using $\mathrm{Ni}$ and Zeolite as catalysts at $700-800{ }^{\circ} \mathrm{C}$ \\
\hline
\end{tabular}

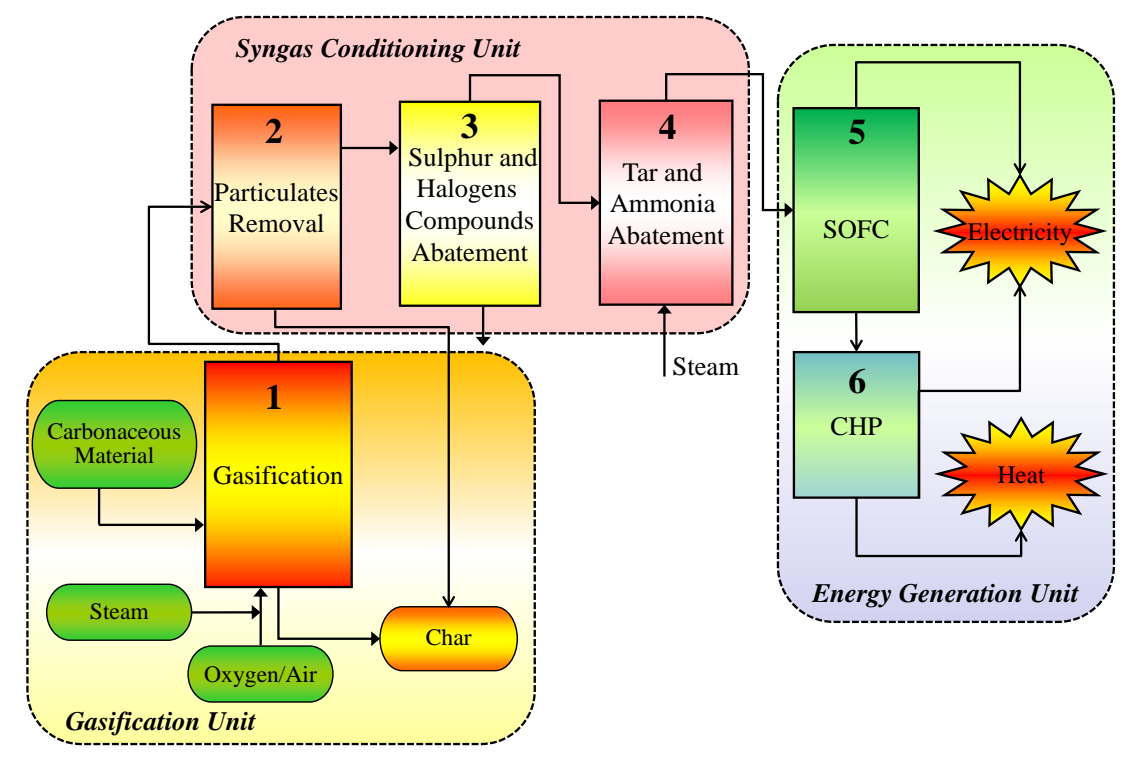

Figure 1. Proposal diagram for hot syngas cleaning and conditioning to be used in SOFC.

Due to SOFC intolerance to some syngas impurities, syngas conditioning is required and is still a challenge. However, recent developments in hot gas cleaning/upgrading technologies would improve reliability and efficiency and lower the costs. In addition to the technical aspects of syngas cleaning and conditioning procedures, cost and environmental impact of these processes are of major importance, as they will affect, and may even compromise, the viability of the overall process from syngas production by gasification up to syngas end-use in SOFC. Further research and demonstration plants are still needed to the overall reliability and costs decrease. 


\section{Solid Oxide Fuel Cells (SOFCs) Combined Heat and Power (CHP) Production 4.1. Introduction}

There have been an increasing number of studies, in the literature, on integrated biomass gasification and SOFC systems for CHP production. These studies include biomass gasification, gas cleaning system and high temperature FCs (fuel cells). The increased development of the fuel cell-based cogeneration system has contributed to the rise of publications and to the development of commercial products in the last years [76]. These publications consider the FCs as the most promising cogeneration systems. In USA there is a program that aims to advance SOFC gasification systems [77]. This program is focused on the design, scale-up and integration of the SOFC technology into modules and systems, and in the development and testing of progressively larger stacks/systems.

The FCs are one of the most suitable devices to generate electricity and heat in a continuous mode [77]. FCs operate as energy conversion devices generating electricity, thermodynamically and electrochemically, from the reactions between hydrogen and oxygen. An important advantage of the FC is that, apart from electricity, it also generates heat, water and lesser carbon per $\mathrm{kWh}$ energy produced when compared to conventional combustion engines using hydrocarbons as fuel. Additionally, a high temperature FC system fed with biogas can achieve higher efficiency than a conventional electricity-generation system (gas turbines). For instance a $100 \mathrm{~kW}$ SOFC can achieve about $48.7 \%$ of efficiency while a conventional electricity-generation system, based on gas turbines, typically presents $41.5 \%$ (thermal efficiency power based) [78].

The conventional CHP technologies using, as fuels, solid biomass have often shown restricted fuel flexibility, limited electric efficiencies and high particulate matter emissions. So, the integration of biomass gasification and FC seems to be a good option for producing CHP using solid biomass, with high efficiency and reduced environmental impact [79], however there are still challenges to be overcome. The main challenges include: (i) management of biomass feedstock with the searching of the most abundant biomass type, storage, transportation and size to be used in the gasifier; (ii) the optimization of gasification process, namely operating parameters (temperature, type of gasifying agent, type of biomass, equivalent ratio, etc.); (iii) gas cleaning systems to meet the gas purity requirement of FCs; (iv) development of materials for FCs, especially anode development, in order to increase the electrochemical performance, stability and, also, rise the tolerance to the presence of $\mathrm{H}_{2} \mathrm{~S}$ and carbon deposition and (v) application of the electricity and heat from FC based CHP [80].

The three first points were already addressed in the previous chapters. This chapter will be focused in the FC options available for the CHP production using syngas from biomass gasification. The most studied FCs for this application are the high temperatures ones, especially SOFC. However, some studies comparing the most developed types of FC within the high temperature group (MCFC and SOFC) were performed [77,78]. Karvountzi et al. [81] concluded that both MCFC and SOFC could be successfully integrated in a hybrid system achieving much higher efficiencies than the conventional power plants. Additionally, Varbanov and Klemes [82] compared the integration of a SOFC + GT (solid oxide fuel cell + gas turbine) and of a MCFC + ST (molten carbonate fuel cell + steam cycle) and concluded that in the SOFC + GT system, the components are more firmly integrated, which leads to high efficiency, but also presents smaller driving forces, which can increase the capital costs. For the MCFC + ST the driving forces are much larger, which enables smaller capital costs for the heat recovery combination still maintaining high efficiency. The main limitation of MCFCs is corrosion and complex handling, due to the use of molten carbonate liquid as an electrolyte at high operating temperature, which limits the options for construction materials. In the same way, the high temperature of operation of SOFC also limits the choices of materials that can be thermally, catalytically and conductively stable at high temperatures [83]. However, in the majority of the studies SOFC seems to be the most suitable FC to be employed in cogeneration systems due to high electrical efficiency $(40-60 \%)$ [84] and excess heat produced during the reaction that can be used for 
cogeneration [85]. This type of cells can provide an efficiency of about $90 \%$ in combined heat and power (CHP) operation [80]. Additionally, unlike other types of FCs, SOFCs have a wide adaptability to different fuels and are more tolerant to impurities. The SOFCs can use, besides hydrogen, hydrocarbon gases (i.e., biogas), liquids (i.e., methanol) and even solids as fuel. The use of natural gas or other hydrocarbons as fuels in the SOFC is possible due to its internal reforming process (I.R.), which allows hydrogen production without the need of an external reformer. Studies suggest that the efficiency of external reforming is $8 \%$ lower than that of internal ones [80].

It is the catalytic activity of anode that allows the internal reforming of the fuel, that is, the catalyst layer present at the anode acts as the reformer to convert hydrocarbon and oxygen components to $\mathrm{H}_{2}$. In addition, more $\mathrm{H}_{2}$ and $\mathrm{CO}$ can be produced internally by steam reforming of $\mathrm{CH}_{4}$. This reaction and the conversion of $\mathrm{CO}$ into $\mathrm{CO}_{2}$ and $\mathrm{H}_{2}$ takes place at the anode-electrolyte interface and also in the anode, due to the presence of the catalyst, which promotes the steam reforming and water gas shift reactions. In addition, the water formed in the oxidation of the $\mathrm{H}_{2}$, by electrochemical activity in the $\mathrm{FC}$, is useful for the water gas shift or reforming reactions [2].

The characteristics of the SOFC, already mentioned, showed that this device is a good candidate for the CHP production integrated with biomass gasification. The use of syngas as fuel for SOFC has been studied by several researchers that concluded that the integration of SOFC and gasification is suitable for the standalone applications system, however, the electrochemical performance of the SOFC operating with biomass-derived fuel is lower than the SOFC working with hydrogen. Nevertheless, this integration system can still be the alternative for the use of biomass derived-fuel avoiding the high cost of transportation and use of commercial hydrogen [80]. Additionally, when compared with conventional power generation systems (combustion engines, gas turbines, gas motors and diesel motors) SOFC has lower operating temperature and higher efficiency. A study of the application of syngas produced from biomass gasification as fuel for a planar solid oxide fuel cell (SOFC) was performed by Shi et al. [86]. In this study was used a simulated syngas based on the composition of biomass gasification syngas without $\mathrm{N}_{2}$. The syngas and the compressed air were introduced into the anode and cathode of SOFCs, respectively. The steam reforming of this syngas was carried out at the anode of the SOFC to obtain a hydrogen-rich fuel. The performance of the SOFCs by I-V polarization was investigated and electrochemical impedance spectra characterizations and an excellent cell performance was observed. Moreover, the operation of the SOFC using the simulated syngas showed high stability [86]. However, there still remain some main barriers to be overcome before the widespread use of the SOFC with real syngas. One of the major problems regarding direct $\mathrm{H} / \mathrm{C}$ fuel utilization is the Ni-based anode degradation, which is due, normally, to the unfavorable reactions and poisoning from carbon and/or sulphur species [78]. Usually, in the fuels to be used in SOFC, the sulphur appears in the form of $\mathrm{H}_{2} \mathrm{~S}$ and, even after the desulfurization processes previous its feeding into the cell, the $\mathrm{H}_{2} \mathrm{~S}$ remains in critical concentrations (between 0.1 and $15 \mathrm{ppm}$ ) for the cell's performance and lifetime [78]. So, the two main options are: remove completely sulphur from the fuel before feeding it into the cell or develop sulphur tolerant anodes.

\subsection{Development of New Materials}

The recent research has been focused on the development of new materials for the anode, electrolyte and cathode of the SOFC, especially for the anode to increase its tolerance to the sulphur and prevent carbon deposition, allowing higher energy efficiency for the integrated system. The aim is to improve chemical stability and electrochemical performance of the FC.

The SOFC conventionally employs the Ni added to yttria-stabilized zirconia (YSZ), Gd-doped ceria (GDC) or ceria gadolinium oxide (CGO) as the anode. Scandia-stabilizedzirconia (SSZ), YSZ or GDC is used to fabricate the electrolyte part, while lanthanum strontium manganite (LSM) or lanthanum strontium cobaltite (LSC) is used as the cathode 
either alone or together with the electrolyte. The most common SOFC electrolyte is YSZ due to its exceptional electrochemical properties but SSZ and GDC are also used. For the anode $\mathrm{Ni}$ added to YSZ, GDC or CGO is used, but the most used is the NiO/YSZ anode [80,87].

Most of the research on the new materials developed is centralized on the anode due to its important role in the catalytic activity in the electro-oxidation of the fuels, so, alternatives to the Ni/YSZ are being studied $[2,79,88]$. Furthermore one critical challenge of the implementation of fuel-flexible and cost-effective SOFC systems is the development of anode materials more tolerant, especially to sulphur contaminates [2]. In SOFCs the carbon formation and deposit occurs during the internal reforming and oxidation reactions of the hydrocarbons and one of the main factors that influence its formation is the nature of the catalyst/anode cermet [78].

Besides the high tolerance to contaminants, the anode has to fulfill other requirements, especially to have excellent catalytic activity for electro-oxidation of the fuels. So, the main requirements that an anode has to satisfy are: (i) appropriate porosity to allow the fuel molecules to easily move toward and the removal of the reaction products; (ii) high electronic conductivity; (iii) high catalytic activity toward electro-oxidation of the possible fuels; (iv) high tolerance to fuel contaminants and low propensity for carbon deposition; (v) high surface to volume ratio; (vi) matching thermal expansion coefficient with electrolyte; (vii) chemical compatibility with electrolyte and (viii) mechanical strength [78]. Moreover, to have the possibility to be implemented commercially, the anode has to be robust and compatible with the other SOFC components, to have low cost and be simple to manufacture [80].

The Ni-based anodes have better properties regarding the catalytic activity, electrical conductivity, gas diffusivity and structural integrity so they are the most adequate to be used in the SOFC. However, some problems with Ni based material were identified. These main issues are: (i) in reducing conditions, Ni catalyzes the growth of carbon deposition; (ii) the deposited carbon corrodes the $\mathrm{Ni}$ causing a decrease in conductivity and structural damage of the anode; (iii) presents low tolerance to sulphur species and (iv) it demonstrates poor redox stability. Consequently $\mathrm{Ni}$-free anodes have been studied but the materials tested showed lower catalytic or electrochemical activity, low electronic conduction and thermal stability. Additionally, more expensive materials with high processing cost were used. Some of the materials tested were ruthenium $(\mathrm{Ru})$, copper fluorite, tungsten bronze, etc. [80], but, although some of the results, especially with Ru and rhodium (Rh), were promising regarding carbon deposits formation, its high cost makes their use too expensive for the SOFC applications [78]. So, the Ni-based materials are still considered the most promising.

The Ni/YSZ anode is typically used but, unfortunately, it has low sulphur tolerance and catalyzes the formation of carbon fibers by a mechanism involving carbon deposition followed by dissolution in nickel particles [87].

One of the best candidates to the replacement of the Ni/YSZ is the Ni/GDC anodes that seem to have higher tolerance to the contaminants and so less severe cleaning is required $[2,78]$. This promising behavior may be due to specific properties of GDC, especially of $\mathrm{CeO}_{2}$, which plays a double role in both $\mathrm{H} / \mathrm{Cs}$ reforming and $\mathrm{H}_{2} \mathrm{~S}$ tolerance. It seems that the $\mathrm{CeO}_{2}$ is not severely poisoned by $\mathrm{H} / \mathrm{C}$ fuel mixtures containing up to $100 \mathrm{ppm}$ of $\mathrm{H}_{2} \mathrm{~S}$ and so maintains its catalytic/reforming activity, allowing the production of $\mathrm{H}_{2}$ that is further electrochemically oxidized for the power generation. These observations suggest that the sulphur tolerance and carbon resistance can be improved by the preparation of modified $\mathrm{X}-\mathrm{Ni}$ /Ceria-based anodes, where $\mathrm{X}$ could be $\mathrm{Au}, \mathrm{Ag}, \mathrm{Cu}$ or $\mathrm{Ru}$ [78]. Anodes such as $\mathrm{Ni} / \mathrm{ScSZ}, \mathrm{Ni}$ /rare earth, $\mathrm{Ni} / \mathrm{yttrium}$ doped Ceria have already been studied but to a lesser extent. The high catalytic activity of nickel, in electrochemical oxidation and internal reforming reactions with $\mathrm{H} / \mathrm{C}$ fuels, has placed it as good candidates for anode materials for the SOFC to be used with syngas as fuel.

In Table 7 are presented the main advantages and disadvantages of the most studied materials (Ni-YSZ and Ni-GDC). 
Table 7. Comparison between the Ni-YSZ and Ni-GDC anode $[2,78,80]$.

\begin{tabular}{|c|c|c|}
\hline $\begin{array}{l}\text { Anode Used } \\
\text { Materials }\end{array}$ & Ni-YSZ & Ni-GDC \\
\hline Advantages & $\begin{array}{ll}\text { - } & \text { Relatively low cost cermet } \\
\text { - } & \text { High porosity and electronic conductivity } \\
\text { - } & \text { Ni acts as reforming catalyst } \\
\text { - } & \text { Large anode-electrolyte interface } \\
\text { - } & \text { Matching TEC with electrolyte } \\
\text { - } & \text { Reasonably tolerant to } \mathrm{HCl}\end{array}$ & 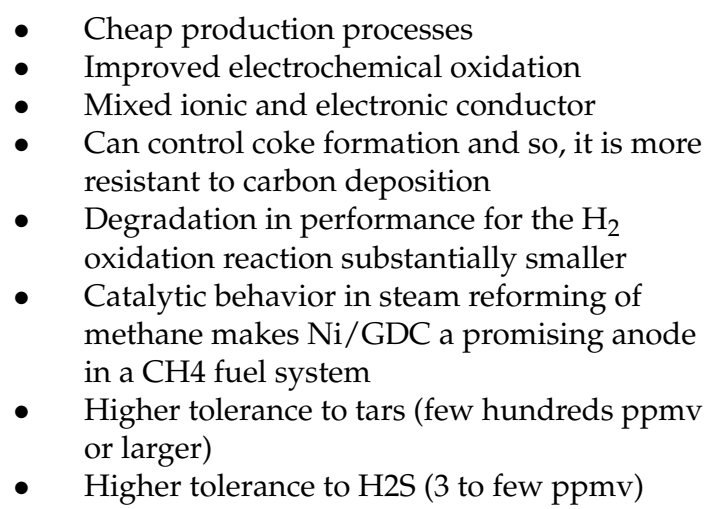 \\
\hline Disadvantages & $\begin{array}{l}\text { Easily poisoned by sulphur (short term } \\
\text { exposure to } \mathrm{H}_{2} \mathrm{~S} \text { in the ppm range always } \\
\text { causes severe voltage drop, which can be } \\
\text { reversible or not). } \\
\text { - Significant reduced sulphur tolerance in the } \\
\text { presence of carbon compounds and/or other } \\
\text { gas contaminants (e.g., As, } \mathrm{P}, \mathrm{Cl} \text { ) in the fuel } \\
\text { Prone to carbon deposition } \\
\text { - } \begin{array}{l}\text { Possible cell cracking caused by cold spots } \\
\text { due to high steam reforming }\end{array}\end{array}$ & $\begin{array}{l}\text { - } \quad \text { Limits operating temperature } \\
\text { - } \quad \text { Replacing Ni with other dopants reduces } \\
\text { - } \quad \text { Ni poisoned by sulphur } \\
\text { - } \quad \text { Needs further studies on } \mathrm{HCl} \text { influence. }\end{array}$ \\
\hline
\end{tabular}

These two anode materials have been investigated to its possible use in the SOFC integrated with the biomass gasification and gas cleaning systems $[2,61,78,80,86,88,89]$. Some of these studies were more focused on the gasification process and gas cleaning in order to meet the requirements of the SOFC for the CHP production, others on the SOFC improvement with the aim of reducing the need of a severe syngas cleaning step. Other researchers looked at the integrated system.

Looking in more detail at the integrated system, the several studies found in the literature showed that the SOFC-CHP biomass fuelled systems seems, not only capable of generating electricity and useful heat, but also can increase the power generation efficiency and reduce the air pollutant emissions [90]. The combination between biomass gasification with a SOFC to produce heat and electricity can potentially contribute to increase the environmental benefits compared to this technologies working separately [79]. The developments in the gasification process, gas cleaning and SOFC allowed increasing the possibility of success of combining all the systems with good results. The gasifier design is a key parameter that affects the composition and quality of produced gas. Two main types of reactor have been considered in the research studies, fluidized and fixed bed. However, it was concluded that the fixed bed downdraft was the suitable gasifier type for biomass gasification because it produces a relatively clean gas (low impurities and low tar level), resulting in a less expensive gas cleaning system [80]. Regarding the gas cleaning systems the authors refer that the hot gas cleaning systems are the most adequate $[61,80]$. A reasonable number of studies with the utilization of the syngas as fuel in a solid oxide fuel cell system have been carried out and the effect of the presence of contaminants, especially $\mathrm{H}_{2} \mathrm{~S}$ was investigated $[2,78]$.

\subsection{CHP Technologies}

The solid biofuel gasification was recently established as an important option for power plants based on combined cycles, achieving efficiencies above $35 \%$ in the $20-40 \mathrm{MWe}$ range. Simultaneously, there has been important research effort to develop efficient small 
scale CHP systems that can use the syngas, produced in gasification processes, in internal combustion engines, microgas turbines or FCs. The conventional small-scale CHP generation (100 kWe to 1 MWe size) based on lignocellulosic biomass consists of two main pathways: biomass gasification or pyrolysis connected to an internal combustion engine (ICE) and to a microgas turbine (MGT); direct combustion in grate or fluidized bed boilers coupled with MGT, Stirling engines, steam turbines or organic Rankine cycle (ORC) [89]. As stated before, currently, the research effort has been especially centralized on the combination of biomass gasification and SOFCs.

The SOFC has been considered a suitable option for efficient integration with other energy conversion technologies namely, gas turbine (GT), steam turbine (ST), organic Rankine cycle (ORC), Stirling engine, etc. [60]. Most of the studies are based in modeling results and present the combination SOFC-GT (gas turbine) as the main option to improve system performance $[61,80,84,90]$, however more complex solutions are also presented but most of them including the GT $[60,79,91]$.

Some studies comparing this conventional CHP with SOFC were performed. A recent study presented by Moretti et al., 2020 [79], compared a biomass-fuelled ORC technology with high-efficiency bio-based power (HBP) technology combining biomass fixed bed gasification with a SOFC to produce heat and electricity. In the HBP, the biomass is gasified and the syngas is submitted to a first tar reforming step and then purified in a gas cleaning unit. Afterwards, the syngas is fed to the SOFC unit to generate electricity, the heat recovery occurs by the burn of the off-gases from the SOFC unit in a catalytic afterburner [79]. The authors stated that the HBP system showed a better performance compared with ORCs, as higher exergy efficiencies and particulate emissions close to zero were observed.

Bang-Møller et al. [92] investigated a CHP plant combining a two-stage gasification process and SOFCs. In this two-stage gasification process is obtained a very clean syngas so only a simple gas conditioning system is needed. The syngas is converted to electric power and heat in the CHP producing block, which is composed by an SOFC stack and a burner. An efficient power production from the syngas is assured by the SOFC, and the SOFC off gases are sent to the burner to ensure complete oxidation of the residual fuel [93].

Three different CHP plant concepts based on biomass gasification were evaluated by Bang-Møller and Rokni [94], using thermodynamic modeling combining zero-dimensional component models. The syngas produced during the biomass gasification was used for electricity production in (i) a microgas turbine (MGT) in the first system, (ii) in a SOFC in the second system and (iii) in a combined SOFC-MGT in the third system. The results showed that the most efficient system was the biomass gasification combined with the SOFC-MGT, this was due the utilization of excess fuel and heat from the SOFC unit in the MGT. In the combination SOFC and MGT, the unconverted syngas from the SOFC was used to produce more power in the MGT, which improves the efficiency. Regarding the other two configurations, the SOFC converted the syngas more efficiently than the MGT.

Toonssen et al. [61] investigated the influence of gasification, gas cleaning technology and system scale on the performance of an integrated biomass gasification-SOFC/GT system. The small scale systems showed lower efficiency than the large scale ones, due to lower exergy losses. Efficiencies of about $60 \%$ (LHV) can be attainable for large scale plants [92]. For small scale plants, efficiencies of about approximately $40 \%$ (LHV) were presented by Fryda et al. [95], this value was achieved by the best performing coupling system tested, using SOFC and MGT combined.

Fryda et al. [95] modeled, using the Aspen Plus ${ }^{\mathrm{TM}}$ process simulation software, a hybrid CHP system consisting of an autothermal gasifier (fluidized bed air blown gasifier) and feeding of a microgas turbine (MGT), an SOFC or both combined. It assessed integrated systems working near atmospheric and at elevated pressures combined with a microgas turbine (MGT) expander. These authors compared three small scale combined heat and power (CHP) configurations integrating the following technologies: (i) gasification at 4 bar and MGT, (ii) near atmospheric gasification and SOFC and (iii) gasification at 4 bar and 
SOFC-MGT. The MGT system proved to be more efficient than the atmospheric SOFC, but the SOFC-MGT showed the best performance reaching the highest exergetic electrical efficiency. They also observed that the small difference between pressures did not have significant effect on the product gas composition or on the exergetic efficiency of the gasification process. However, at higher pressure the SOFC operation was greatly improved, with the production of additional power from an MGT expander [94].

More recently Zhao et al. [84], also using the Aspen Plus ${ }^{\mathrm{TM}}$ software, proposed a power generation system including two blocks: (1) separated-type biomass gasification system composed by a pyrolyser, a tar reformer, a bio-char combustor, a volatiles combustor and a syngas purifier and (2) electrical power generation process with a SOFC and a gas turbine. In this process, the syngas produced in the gasification system, after purification, compression and heating is fed to the SOFC and the unreacted syngas in SOFCs is converted to electrical power by the gas turbine. Furthermore, the large amount of energy/exergy in the form of heat, discharged from the gas turbine, can be reused for the preheating of syngas and air before entering the SOFC [84].

Other solutions, more complex, but including GT were also tested and reported. Borji et al. [93] performed a thermodynamic simulation of an integrated CHP plant composed by a downdraft fixed bed gasifier, an SOFC (anode-supported co-flow single intermediate-temperature planar cell), a MGT and a heat recovery steam generator (HRSG). The CHP system comprises an autothermal gasification process and a CHP producing section. The gas produced in the biomass gasification process is converted to electric power and heat in the second part of the integrated plant. This part is composed of the SOFC stack, the MGT, an afterburner and a HRSG. The electricity is produced by the SOFC using the syngas. The unreacted gases and air streams from the SOFC are sent to an afterburner producing heat, which is used to heat up the gas mixture. Additional power is produced by the MGT using the residual fuel contained in the off gases of the SOFC. At the end, a superheated steam is generated by the HRSG using the waste heat from the exhaust, which can be used for heat production.

A HRSG was also included in the cogeneration system proposed by Roy et al. [60], but an externally fired gas turbine (EFGT) was considered instead of the MGT. These authors performed modeling and analysis of an integrated cogeneration system for heat and power generation, which included a biomass gasifier, a SOFC module, an externally fired gas turbine (EFGT) block and a HRSG. The EFGT block is composed by air compressor, a heat exchanger and an air turbine unit. After being treated and conditioned the syngas is preheated and supplied to the SOFC. The preheated compressed air is further expanded at the AT (air turbine) unit, where additional power is obtained. The fuel not consumed in the SOFC unit is completely burnt in the afterburner unit. Like in Borji et al. [93], in this system, saturated steam is also generated by HRSG using the waste heat from the exhaust gases. Exergetic and economic methods were used to evaluate the proposed system [60]. The same authors had proposed, in another study, a single system combining a downdraft biomass gasifier integrated with the gas cleaning unit, SOFC, EFGT and ORC $[89,96]$. The main difference was the introduction of an ORC in order to recover the residual heat available in the hot exhaust gas coming out from the secondary heat exchanger. Additionally, it was introduced a heat recovery vapor heater $(\mathrm{HRVH})$ to heat up the working fluid of ORC. The HRSG was not considered.

Although the traditional GT, especially the MGT seems to be the choice of the most performed studies, the EFGT technology has been, also proposed, as a solution for increasing the biomass gasification-SOFC system performance. However, only a few studies on the integration of EFGT technology with the biomass gasification process have been performed [60]. Comparing with the traditional GT, the EFGT has the advantage of the dirty flue gas not touching the turbine blades directly, so their lifetime increases. Therefore, the integration of EFGT or indirectly heated GT with the SOFC technology has arisen as another possible option for power production or waste heat recovery [60]. 
A different combination was proposed by Wu et al., 2020 with the integration of the SOFC with a HCCI engine instead of the GT. So, the main difference of this system is the use of HCCI (homogeneous charge compression ignition) engine subsystems that uses the SOFC off-gas for additional power generation, hence improving the energy conversion efficiency of the system. This proposal includes also a biomass gasifier, a reformer SOFC and a waste heat recovery (WHR) unit. Most of the power generation of the system comes from the reformer of the SOFC subsystem that, also, produces the fuel for the downstream engine by steam reforming and water gas shift reactions. WHR subsystem recycles the waste heat of the SOFC and HCCI engine.

All the researcher studies in this field concluded that the SOFC is the most adequate device to be used in the CHP production from biomass gasification. However, as stated before, it is very important the development of new materials especially for the anode. Actually, based on the published results Ni/GDC shows enhanced sulphur tolerance in the presence of $\mathrm{H} / \mathrm{C}$-based fuels and so, they seem to be the most favorable to be used in a biomass integrated gasification-SOFC systems. These anodes are able to operate with fuels with a few hundred of ppm of tar. In this case catalytic cracking using dolomite in secondary bed could be selected. However for long term continuous operation thermal cracking could be considered. The utilization of the Ni/GDC instead of Ni/YSZ avoids the additional tar removal using the Ni based catalyst, decreasing the costs associated with the gas cleaning system. Additionally, as stated before, the Ni/GDC anode is relatively more tolerant to biomass gasification tars and a stable cell performance is achieved for extended periods of time without considerable problems in the presence of more $\mathrm{H}_{2} \mathrm{~S}$ and $\mathrm{HCl}$ content. Thus a careful selection of biomass feedstock with less $\mathrm{S}$ and $\mathrm{Cl}$ contents should be done to avoid the cleaning units for tar, $\mathrm{H}_{2} \mathrm{~S}$ and $\mathrm{HCl}$. So, using the Ni/GDC anode probably the gas cleaning chain could be shortened being the system reduced to gasifier, particulate removal (ceramic filter) at $800{ }^{\circ} \mathrm{C}$, alkali getters at $80{ }^{\circ} \mathrm{C}$ and SOFC [2]. Additionally, the best solution for the increasing of performance of the CHP production from biomass gasification-SOFC systems has to be considered. This is an issue still in development as many combinations can be tested. However, taking into account the studies already performed, the SOFC-MGT combination with the integration of an HRSG seems a good choice. The proposed combination is presented in Figure 2, which details the energy generation unit shown in Figure 1.

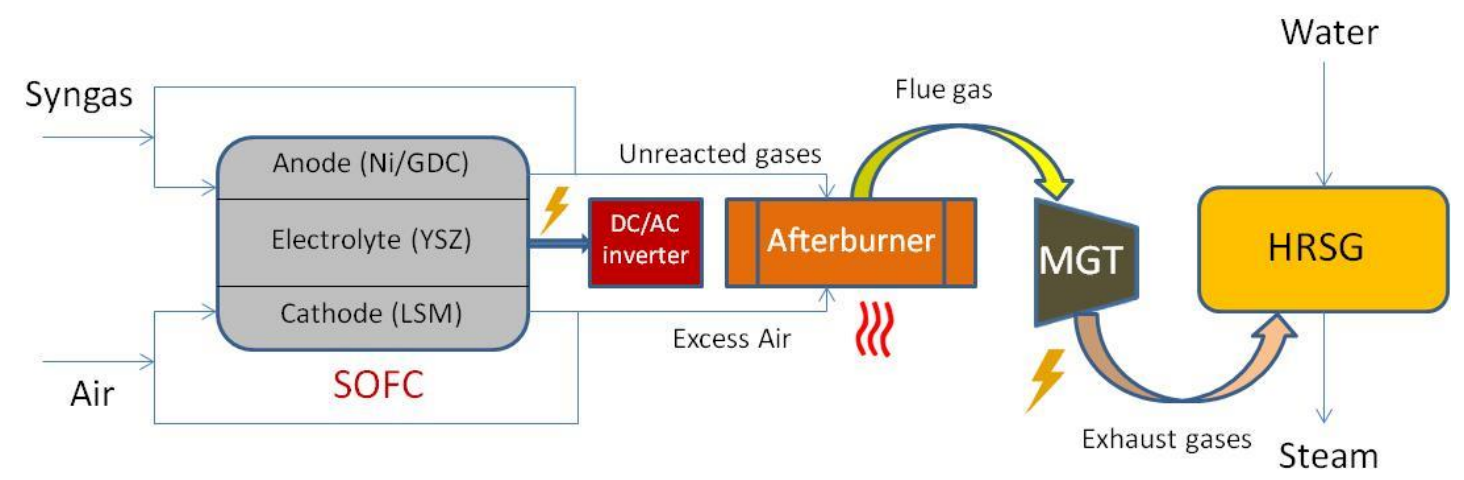

Figure 2. Scheme of a proposed system for combined SOFC-CHP (SOFC—solid oxide fuel cell; MGT—microgas turbine; HRSG-heat recovery steam generator).

\section{Conclusions}

The combination of biomass gasification and high-temperature FC, like SOFC, combined with heat and power offers a great potential as a future sustainable, green, power generation system and thus has attracted a lot of attention from researchers in the last years. These systems include three main integrated blocks, biomass gasification, gas conditioning system and energy generation by SOFC and CHP. In this review paper, the main achievement and challenges of each of these processes were assessed. 
The main challenges regarding biomass and wastes gasification is the applicability of the process to mixed feedstock with higher contents of moisture and hazardous contaminants, with minimization of fouling and slagging. So, it is very important to develop new gasification technologies with more fuel flexibility. Another important issue is to reduce the capital and operating costs and to increase the durability of the building materials and refractories, for that, processes allowing suitable operation temperatures but maintaining the quality of the syngas produced. The production of clean syngas with minor needs of conditioning and upgrading to achieve the requirements to be used in the SOFC is imperative.

Up to now, usually syngas produced in existing commercial gasifiers cannot meet the requirements to be used in SOFC, so generally downstream clean up and conditioning are required. The syngas cleaning and condition is a crucial point in its application as fuel in the SOFC, due to its intolerance to some syngas impurities, so syngas conditioning is mandatory and is still a challenge. The overall system has still technical aspects to overcome, but the cost and environmental impact of these processes will greatly affect, and even compromise, the viability of the overall integrated process of gasification-SOFCCHP. However, recent developments in hot gas cleaning/upgrading technologies showed that reliability and efficiency can be improved and the costs reduced.

All the researcher studies found in this field stated that among the more developed FC, the high-temperature SOFC is the most suitable candidate for biomass power conversion technologies, due to its fuel flexibility, tolerance to some fuel contaminants, high electricity conversion efficiency and its operating temperature close to the biomass gasification process. However, one of the crucial points of the implementation of fuel-flexible and cost-effective SOFC systems is the development of new materials, especially for the anode to increase its tolerance to sulphur and prevent carbon deposition and thus to improve the chemical stability and electrochemical performance of SOFC. The most commonly used and more developed anode material is Ni/YSZ, but its low tolerance to contaminants, especially $\mathrm{H}_{2} \mathrm{~S}$ and formation of carbon deposits, had led to the search of alternatives. The Ni/GDC anode is relatively more tolerant to syngas contaminants, especially tars, $\mathrm{H}_{2} \mathrm{~S}$ and $\mathrm{HCl}$, so, using this anode material, the gas cleaning chain could probably be shortened.

Further research is still needed as studies suggest that the sulphur tolerance and carbon resistance can be further improved, for instance, using modified X-Ni/Ceria-based anodes.

The most favorable CHP solutions involving the SOFC are still an issue in development as many combinations were tested and still other can be assessed. However, taking into account the studies already performed, the SOFC-MGT with the addition of a HRSG seems a good choice, due to the MGT and HRSG being well established technologies already implemented in combustion processes. The integrated biomass gasification and solid oxide fuel cell systems for CHP production are proven to be an option for the conventional technologies based on fossil fuels with high environmental benefits, but further research and demonstration plants are still needed to prove the sustainability of these integrated processes and to decrease the costs.

Author Contributions: Writing—Original Draft Preparation, P.C., F.P., R.N.A. and P.M.; Introduction, P.M.; Section 2. Biomass Gasification for Syngas Production, R.N.A.; Section 3. Syngas Cleaning and Conditioning, F.P.; Section 4. Solid Oxide Fuel Cells (SOFCs) Combined Heat and Power (CHP) Production, P.C.; Conclusions, P.C., F.P., R.N.A. and P.M.; References, P.C., F.P. and R.N.A.; Writing-Review \& Editing, P.C., F.P. and R.N.A. All authors have read and agreed to the published version of the manuscript.

Funding: This research was funded by European Union's Horizon 2020 research and innovation program, grant agreement $\mathrm{N}^{\mathrm{o}} 731101$.

Institutional Review Board Statement: Not applicable.

Informed Consent Statement: Not applicable. 


\section{Data Availability Statement: Not applicable.}

Acknowledgments: This work was supported by BRISK 2-Biofuels Research Infrastructure for Sharing Knowledge II, project that has received funding from the European Union's Horizon 2020 research and innovation program under grant agreement $\mathrm{N}^{\circ} 731101$.

Conflicts of Interest: The authors declare no conflict of interest.

\section{References}

1. Pinto, F.; André, R.N. The role of gasification in achieving almost zero emissions in energy production from coal. In Fossil Fuels: Sources, Environmental Concerns and Waste Management Practices; Kumar, R., Ed.; Nova Science Publishers, Inc.: New York, NY, USA, 2013; pp. 145-198. ISBN 978-1-62808-412-2.

2. Din, Z.U.; Zainal, Z.A. The fate of SOFC anodes under biomass producer gas contaminants. Renew. Sustain. Energy Rev. 2017, 72, 1050-1066. [CrossRef]

3. Ren, J.; Cao, J.-P.; Zhao, X.-Y.; Yang, F.-L.G.; Wei, X.-Y. Recent advances in syngas production from biomass catalytic gasification: A critical review on reactors, catalysts, catalytic mechanisms and mathematical models. Renew. Sustain. Energy Rev. 2019, 116, 109426. [CrossRef]

4. Pinto, F.; André, R.N.; Carolino, C.; Miranda, M. Hot treatment and upgrading of syngas obtained by co-gasification of coal and wastes. Fuel Process. Technol. 2014, 126, 19-29. [CrossRef]

5. Watson, J.; Zhang, Y.; Si, B.; Chen, W.-T.; de Souza, R. Gasification of biowaste: A critical review and outlooks. Renew. Sustain. Energy Rev. 2018, 83, 1-17. [CrossRef]

6. Pinto, F.; André, R.N.; Lopes, H.; Franco, C.; Carolino, C.; Costa, R.; Miranda, M.; Gulyurtlu, I. Comparison of a pilot scale gasification installation performance when air or oxygen is used as gasification medium 1 . Tars and gaseous hydrocarbons formation. Fuel 2012, 101, 102-114. [CrossRef]

7. Pinto, F.; André, R.N.; Lopes, H.; Franco, C.; Carolino, C.; Costa, R.; Miranda, M.; Gulyurtlu, I. Comparison of a pilot scale gasification installation performance when air or oxygen is used as gasification medium 2-Sulphur and nitrogen compounds abatement. Fuel 2012, 97, 770-782. [CrossRef]

8. Pinto, F.; André, R.N.; Miranda, M.; Neves, D.; Varela, F.; Santos, J. Effect of gasification agent on co-gasification of rice production wastes mixtures. Fuel 2016, 180, 407-416. [CrossRef]

9. Hauch, A.; Küngas, R.; Blennow, P.; Hansen, A.B.; Hansen, J.B.; Mathiesen, B.V.; Mog, M.B. Recent advances in solid oxide cell technology for electrolysis. Science 2020, 370, 6513. [CrossRef]

10. Pinto, F.; Gominho, J.; André, R.N.; Miranda, M.; Gonçalves, D.; Varela, F.; Neves, D.; Santos, J.; Lourenço, A.; Pereira, H. Effect of rice husk torrefaction on syngas production and quality. Energy Fuels 2017, 31, 5183-5192. [CrossRef]

11. Thomson, R.; Kwong, P.; Ahmad, E.; Nigam, K.D.P. Clean syngas from small commercial biomass gasifiers; a review of gasifier development, recent advances and performance evaluation. Int. J. Hydrog. Energy 2020, 45, 21087-21111. [CrossRef]

12. Indrawan, N.; Kumar, A.; Moliere, M.; Sallam, K.A.; Huhnke, R.L. Distributed power generation via gasification of biomass and municipal solid waste: A review. J. Energy Inst. 2020, 93, 2293-2313. [CrossRef]

13. Vilches, T.B.; Lind, F.; Ryden, M.; Thunman, H. Experience of more than $1000 \mathrm{~h}$ of operation with oxygen carriers and solid biomass at large scale. Appl. Energy 2017, 190, 1174-1183. [CrossRef]

14. Basu, P. Biomass Gasification and Pyrolysis_Practical Design and Theory, 1st ed.; Elsevier Inc.: Amsterdam, The Netherlands, 2010.

15. Phounglamcheik, A.; Babler, M.U.; Donag, P.; Amovic, M.; Ljunggren, R.; Engvall, K. Pyrolysis of wood in a rotary kiln pyrolyzer: Modeling and pilot plant trials. Energy Procedia 2017, 105, 908-913. [CrossRef]

16. Aries Clean Energy. Clean Energy Brochure. Available online: https:/ / ariescleanenergy.com/downloads/ (accessed on 15 December 2020).

17. Technology BE. Bioresidues Energy Technology. Available online: www.betpl.net (accessed on 15 December 2020).

18. Holzenergie Wegscheid. Available online: www.holzenergie-wegscheid.de (accessed on 15 December 2020).

19. Ltd IEP. Infinite Energy. Available online: www.infiniteenergyindia.com (accessed on 15 December 2020).

20. Lipro Energy. Available online: https:/ /ipro-energy.de/en/innovative-technology/ (accessed on 15 December 2020).

21. URBAS Woodgas CHP-Technology. Available online: https://www.urbas.at/en/energietechnik/ (accessed on 15 December 2020).

22. Spanner $\operatorname{Re}^{2}$ Wood Cogeneration Plants. Available online: https://www.holz-kraft.com/images/press_release/2016/161128_ spanner_uk-renewablecompanyaward1.pdf (accessed on 15 December 2020).

23. Ronda Engineering: Ecogas Generator. Available online: http://www.ecogasgenerator.com/ (accessed on 15 December 2020).

24. Xylowatt. Available online: www.xylowatt.com (accessed on 15 December 2020).

25. Brynda, J.; Skoblia, S.; Beno, Z.; Pohorely, M.; Mosko, J. Application of the GP750 Gasifier for Combined Heat and Power Production. In Paper Presented at Biomass to Power and Heat. 2017. Available online: https://www.researchgate.net/publication/3175 44057_Application_of_the_GP750_Gasifier_for_Combined_Heat_and_Power_Production (accessed on 15 December 2020).

26. CPC_Community Power Corporation. Available online: www.gocpc.com (accessed on 15 December 2020).

27. Bio\&Watt Energy from Biomass. Bio\&Watt. Available online: www.bioewatt.com (accessed on 15 December 2020 ). 
28. Klaus, R. CHP with Biomass-Updraft Gasifier in the Range of 400 to $1000 \mathrm{kWel}$. ReGaWatt, 2019. Available online: https: / / www.regawatt.de (accessed on 15 December 2020).

29. Burkhardt Heat and Power with Wood Pellets. Available online: https://burkhardt-gruppe.de/en/homepage/ (accessed on 15 December 2020).

30. Systems PE. Biomass and Waste Gasification. Available online: http://www.prmenergy.com/ (accessed on 15 December 2020).

31. Torbed-Energy Technology Application Description. Mortimer Technology Holdings Ltd. Available online: www.torftech.com (accessed on 15 December 2020).

32. Ast NV. AHT Pyrogas. Available online: http:/ / www.aht-pyrogas.de/en/ (accessed on 15 December 2020).

33. Engineering, B. Available online: www.br-eg.com (accessed on 15 December 2020).

34. Barisano, D. Biomass Gasification for Power Production. Country Report-Italy. Innsbruck, Enea. 2017. Available online: http:/ / www.gasificationofbiomass.org/download.php?file=files/file/2017/Innsbruck/CR/Italy.pdf (accessed on 15 December 2020).

35. Group TFE. Terruzzi Fercalx Energy Group. 2019. Available online: http://www.terruzzifercalxgroup.com/en/indexen.php (accessed on 15 December 2020).

36. Chanderpur Works. Available online: www.chanderpur.com (accessed on 15 December 2020).

37. EQTEC. EQTEC Gasifier Technology. Available online: www.eqtec.com (accessed on 15 December 2020).

38. MEVA Energy. Available online: http://mevaenergy.com/technology/ (accessed on 15 December 2020).

39. Cortus Energy. Rolf Ljunggren, 9th International Seminar on Gasification, Malmö. 19 October 2016. Available online: https: / / energiforskmedia.blob.core.windows.net/media/21796/cortus-woodroll-presentation-isg-2016-10-19.pdf (accessed on 15 December 2020).

40. Sentis, L.; Rep, M.; Barisano, D.; Bocci, E.; Hamedani, S.R.; Pallozzi, V.; Tascioni, R. Techno-Economic Analysis of UNIFHY Hydrog.; The Fuel Cells and Hydrog. Joint Undertaking (FCH JU): Brussels, Belgium, 2016.

41. Van der Meijden, C.M.; Veringa, H.J.; Rabou, L.P. The production of synthetic natural gas (SNG): A comparison of three wood gasification systems for energy balance and overall efficiency. Biomass Bioenergy 2000, 34, 302-311. [CrossRef]

42. Konemann, J.-W. Development of biomass and waste gasification towards green chemicals. In Proceedings of the 2017 Syngas Technologies Conference, Global Syngas Technologies Council, Colorado Springs, CO, USA, 15-18 October 2017; pp. 1-19.

43. Bhoi, P.R.; Huhnke, R.L.; Kumar, A.; Thapa, S.; Indrawan, N. Scale-up of a downdraft gasifier system for commercial scale mobile power generation. Renew. Energy 2018, 118, 25-33.

44. Indrawan, N.; Kumar, A.; Kumar, S. Recent advances in power generation through biomass and municipal solid waste gasification. In Coal and Biomass Gasification: Recent Advances and Future Challenges; De, S., Moholkar, V., Bhaskar, T., Agarwal, A., Eds.; Springer: Singapore, 2018; pp. 369-402.

45. Henriksen, U.; Ahrenfeldt, J.; Jensen, T.K.; Gøbel, B.; Bentzen, J.D.; Hindsgaul, C.; Sørensen, L.H. The design, construction and operation of a 75kW two-stage gasifier. Energy 2006, 31, 1542-1553. [CrossRef]

46. Heidenreich, S.; Foscolo, P.U. New concepts in biomass gasification. Prog. Energy Combust. Sci. 2015, 46, 72-95. [CrossRef]

47. Rauch, R.; Hofbauer, H.; Bosch, K.; Siefert, I.; Aichernig, C.; Tremmel, H. Steam gasification of biomass at CHP plant in guessingstatus of the demonstration plant. In Proceedings of the Second World Conference and Technology Exhibition, Rome, Italy, 10-14 May 2004; pp. 1-4.

48. Xiao, X.; Meng, X.; Le, D.D.; Takarada, T. Two-stage steam gasification of waste biomass in fluidized bed at low temperature: Parametric investigations and performance optimization. Bioresour. Technol. 2011, 102, 1975-1981. [CrossRef]

49. Pei, H.; Wang, X.; Dai, X.; Jin, B.; Huang, Y. A novel two-stage biomass gasification concept: Design and operation of a 1.5 MWth demonstration plant. Bioresour. Technol. 2018, 267, 102-109. [CrossRef]

50. Haspel, A.E. Ionic Gasification Breakthrough Technology for On-Site Waste-To-Energy Conversion. Cogent Energy Systems 2019. Available online: https:/ /www.cogentenergysystems.com/ (accessed on 15 December 2020).

51. SynCraft Two Stage Gasifier Engineering Gmbh. 2018. Available online: https:/ / en.syncraft.at/wood-power-plants/overview (accessed on 15 December 2020).

52. Kruse, A. Supercritical water gasification. Biofuels Bioprod. Biorefining Innov. Sustain. Econ. 2008, 2, 415-437. [CrossRef]

53. Yanik, J.J.; Ebale, S.; Kruse, A.; Saglam, M.; Yüksel, M. Biomass gasification in supercritical water: Part 1. Effect of the nature of biomass. Fuel 2007, 86, 2410-2415. [CrossRef]

54. Lanzini, A.; Ferrero, D.; Papurello, D.; Santarelli, M. Reporting degradation from different fuel contaminants in Ni-anode SOFCs. Fuel Cells 2017, 17, 423-433. [CrossRef]

55. Bocci, E.; Di Carlo, A.; McPhail, S.J.; Gallucci, K.; Foscolo, P.U.; Moneti, M.; Villarini, M.; Carlini, M. Biomass to fuel cells state of the art: A review of the most innovative technology solutions. Int. J. Hydrog. Energy 2014, 39, 21876-21895. [CrossRef]

56. Hofmann, P.H.; Panopoulos, K.D.; Aravind, P.V.; Siedlecki, M.; Schweiger, A.; Karl, J.; Ouweltjes, J.P.; Kakaras, E. Operation of solid oxide fuel cell on biomass product gas with tar levels $>10 \mathrm{~g}$ Nm-3. Int. J. Hydrog. Energy 2009, 34, 9203-9212. [CrossRef]

57. Milne, T.A.; Evans, R.J. Biomass gasifier "Tars": Their Nature, Formation and Conservation; NREL/TP-570-25357; National Renewable Energy Laboratory: Goldern, CO, USA, 1998.

58. Mondal, P.; Dang, G.S.; Garg, M.O. Syngas production through gasification and clean-up for downstream applications-Recent developments. Fuel Process. Technol. 2011, 92, 1395-1410. [CrossRef] 
59. Asadullah, M. Biomass gasification gas cleaning for downstream applications: A comparative critical review. Renew. Sustain. Energy Rev. 2014, 40, 118-132. [CrossRef]

60. Roy, D.; Samanta, S.; Ghosh, S. Performance optimization through response surface methodology of an integrated biomass gasification based combined heat and power plant employing solid oxide fuel cell and externally fired gas turbine. Energy Convers. Manag. 2020, 222, 113182-113200. [CrossRef]

61. Toonssen, R.; Sollai, S.; Aravind, P.V.; Woudstra, N.; Verkooijen, A.H.M. Alternative system designs of biomass gasification SOFC/GT hybrid systems. Int. J. Hydrog. Energy 2011, 36, 10414-10425. [CrossRef]

62. Karmakar, M.K.; Chandra, P.; Chatterjee, P.K. A review on the fuel gas cleaning technologies in gasification process. J. Environ. Chem. Eng. 2015, 3, 689-702.

63. Dayton, D. A Review of the Literature on Catalytic Biomass Tar Destruction-Milestone Completion Report; NREL/TP-510-32815; National Renewable Energy Laboratory: Goldern, CO, USA, 2002.

64. Wang, L.; Weller, C.L.; Jones, D.D.; Hanna, M.A. Contemporary issues in thermal gasification of biomass and its application to electricity and fuel production. Biomass Bioenergy 2008, 32, 573-581. [CrossRef]

65. Rapagnà, S.; Provendier, H.; Petit, C.; Kiennemann, A.; Foscolo, P.U. Development of catalysts suitable for Hydrog. or syn-gas production from biomass gasification. Biomass Bioenergy 2002, 22, 377-388. [CrossRef]

66. Cal, M.P.; Strickler, B.W.; Lizzio, A.A.; Gangwal, S.K. High temperature Hydrog. sulfide adsorption on activated carbon II. Effects of gas temperature, gas pressure and sorbent Regeneration. Carbon 2000, 38, 1767-1774.

67. Zevenhoven, R.; Kilpinen, P. Control of Pollutants in Flue Gases and Fuel Gases; Espoo University of Technology: Finland: Helsinki, 2001.

68. Atakul, H.; Wakker, J.P. Removal of $\mathrm{H}_{2} \mathrm{~S}$ from fuel gases at high temperatures using MnO/y-A1 ${ }_{2} \mathrm{O}_{3}$. Fuel 1995, 74, 187-191. [CrossRef]

69. Pinto, F.; Lopes, H.; André, R.N.; Gulyurtlu, I.; Cabrita, I. Effect of catalysts in the quality of syngas and by-products obtained by co- gasification of coal and wastes. 1. Tars and nitrogen compounds abatement. Fuel 2007, 86, 2052-2063. [CrossRef]

70. Devi, L.; Ptasinski, K.J.; Janssen, F.J.J.G. A review of the primary measures for tar elimination in biomass gasification processes. Biomass Bioenergy 2003, 24, 125-140. [CrossRef]

71. Wang, W.; Padban, N.; Ye, Z.; Olofsson, G.; Andersson, A.; Bjerle, I. Catalytic hot gas cleaning of fuel gas from an air-blown pressurized fluidized-bed gasifier. Ind. Eng. Chem. Res. 2000, 39, 4075-4081. [CrossRef]

72. Pfeifer, C.; Hofbauer, H. Development of catalytic tar decomposition downstream from a dual fluidized bed biomass steam gasifier. Powder Technol. 2008, 180, 9-16. [CrossRef]

73. Gangwal, S.K.; Gupta, R.P.; Portzer, J.W.; Turk, B.S. Simultaneous removal of H2S and NH3 using metal oxide sorbents. In Proceedings of the Advanced Coal-Based Power \& Environmental Systems '97 Conference, Pittsburgh, PA, USA, 22-24 July 1997; Research Triangle Institute, K. Jothimurugesan, Department of Chemical Engineering Hampton University: Hampton, VA, USA, 1998.

74. Hoogers, G.; Bauen, A.; Chen, E.; Hart, D.; Hinsberger, M.; Hogarth, M.; Stone, R.; Thompsett, D. Fuel Cell Technology Handbook, 1st ed.; Hoogers, G., Ed.; CRC Press: Boca Raton, FL, USA, 2002.

75. Marcantonio, V.; Bocci, E.; Ouweltjes, J.P.; Del Zotto, L.; Monarca, D. Evaluation of sorbents for high temperature removal of tars, Hydrog. sulphide, Hydrog. chloride and ammonia from biomass-derived syngas by using Aspen Plus. Int. J. Hydrog. Energy 2020, 45, 6651-6662. [CrossRef]

76. Ramadhani, F.; Hussain, M.A.; Mokhlis, H. A Comprehensive review and technical guideline for optimal design and operations of fuel cell-based cogeneration systems. Processes 2019, 7, 950. [CrossRef]

77. Shailesh, D.V. U.S. DOE Office of Fossil Energy Solid Oxide Fuel Cell (SOFC) Program. Available online: https: / netl.doe.gov/ sites / default/ files/2020-03/AMR-SOFC-Program-Overview-4-29-2019.pdf (accessed on 11 January 2021).

78. Niakolas, D.K. Review Sulfur poisoning of Ni-based anodes for Solid Oxide Fuel Cells in H/C-based fuels. Appl. Catal. A Gen. 2014, 486, 123-142. [CrossRef]

79. Moretti, C.; Corona, B.; Rühlin, V.; Götz, T.; Martin Junginger, M.; Brunner, T.; Obernberger, I.; Li, S. Combining biomass gasification and solid oxid fuel cell for heat and power generation: An early-stage life cycle assessment. Energies 2020, 13, 2773. [CrossRef]

80. Radenahmad, N.; Azad, A.T.; Saghir, M.; Taweekun, J.; Bakar, M.S.A.; Reza, M.S.; Azad, A.K. A review on biomass derived syngas for SOFC based combined heat and power application. Renew. Sustain. Energy Rev. 2020, 119, 109560. [CrossRef]

81. Karvountzi, G.C.; Price, C.M.; Duby, P.F. Comparison of molten carbonate and solid oxide fuel cells for integration in a hybrid system for cogeneration or tri-generation. ASME Adv. Energy Syst. Div. AES 2004, 44, 139-150.

82. Varbanov, P.; Klemes, J. Analysis and integration of fuel cell combined cycles for development of low-carbon energy technologies. Energy 2008, 33, 1508-1517. [CrossRef]

83. Abdelkareem, M.A.; Elsaid, K.; Wilberforce, T.; Kamil, M.; Sayed, E.T.; Olabi, A. Environmental aspects of fuel cells: A review. Sci. Total Environ. 2021, 752, 141803. [CrossRef] [PubMed]

84. Zhao, Z.; Situmorang, Y.A.; An, P.; Yang, J.; Hao, X.; Rizkiana, J.; Abudula, A.; Guan, G. A biomass-based small-scale power generation system with energy/exergy recuperation. Energy Convers. Manag. 2021, 227, 113623.

85. Gandiglio, M.; De Sario, F.; Lanzini, A.; Bobba, S.; Santarelli, M.; Blengini, G.A. Life cycle assessment of a biogas-fed solid oxide fuel cell (SOFC) integrated in a wastewater treatment plant. Energies 2019, 12, 1611. [CrossRef] 
86. Shi, H.; Li, Q.; Tan, W.; Qiu, H.; Su, C. Solid oxide fuel cells in combination with biomass gasification for electric power generation. Chin. J. Chem. Eng. 2020, 28, 1156-1161. [CrossRef]

87. Jacobson, A.J. Materials for solid oxide fuel cells. Chem. Mater. 2010, 22, 660-674. [CrossRef]

88. Wongchanapai, S.; Iwai, H.; Saito, M.; Yoshida, H. Performance evaluation of an integrated small-scale SOFC-biomass gasification power generation system. J. Power Sources 2012, 216, 314-322. [CrossRef]

89. Wu, Z.; Zhu, P.; Yao, J.; Zhang, S.; Ren, J.; Yang, F.; Zhang, Z. Combined biomass gasification, SOFC, IC engine, and waste heat recovery system for power and heat generation: Energy, exergy, exergoeconomic, environmental (4E) evaluations. Appl. Energy 2020, 279, 115794.

90. Gholamian, E.; Zare, V.; Mousavi, S.M. Integration of biomass gasification with a solid oxide fuel cell in a combined cooling, heating and power system: A thermodynamic and environmental analysis, International. J. Hydrog. Energy 2016, 41, 20396-20406. [CrossRef]

91. Pantaleo, A.M.; Camporeale, S.; Fortunato, B. Small scale biomass CHP: Techno-economic performance of steam vs. gas turbines with bottoming ORC. Energy Procedia 2015, 82, 825-832. [CrossRef]

92. Bang-Møller, C.; Rokni, M.; Elmegaard, B.; Ahrenfeldt, J.; Henriksen, U.B. Decentralized combined heat and power production by two-stage biomass gasification and solid oxide fuel cells. Energy 2013, 58, 527-537. [CrossRef]

93. Borji, M.; Atashkari, K.; Ghorbani, S.; Nariman-Zadeh, N. Parametric analysis and Pareto optimization of an integrated autothermal biomass gasification, solid oxide fuel cell and micro gas turbine CHP system. Int. J. Hydrog. Energy 2015, 40, 14202-14223. [CrossRef]

94. Bang-Møller, C.; Rokni, M. Thermodynamic performance study of biomass gasification, solid oxide fuel cell and micro gas turbine hybrid systems. Energy Convers. Manag. 2010, 51, 2330-2339. [CrossRef]

95. Fryda, L.; Panopoulos, K.D.; Kakaras, E. Integrated CHP with autothermal biomass gasification and SOFC-MGT. Energy Convers. Manag. 2008, 49, 281-290. [CrossRef]

96. Roy, D.; Samantab, S.; Ghosh, S. Techno-economic and environmental analyses of a biomass based system employing solid oxide fuel cell, externally fired gas turbine and organic Rankine cycle. J. Clean. Prod. 2019, 225, 36-57. [CrossRef] 